Caine DJ, Maffulli N (eds): Epidemiology of Pediatric Sports Injuries.

Individual Sports. Med Sport Sci. Basel, Karger, 2005, vol 48, pp 74-119

\title{
Skiing and Snowboarding Injuries
}

\author{
Brent Hagel \\ Assistant Professor, Alberta Centre for Injury Control and Research, Department of \\ Public Health Sciences, University of Alberta, Edmonton, Alta., Canada
}

\begin{abstract}
Objective: To critically examine the literature on skiing and snowboarding injuries in children and adolescents. Data sources: Searched English language articles from: Medline, SPORTDiscus, Cumulative Index to Nursing and Allied Health Literature, Current Contents, and HealthSTAR. The table of contents for Ski Trauma and Skiing Safety Series published by the American Society for Testing and Materials were also examined. MeSH headings included: Sports, Athletic Injuries, and Accidents. Keywords used within these headings were Skiing and/or Snowboarding with focus on children, adolescents, youth, students, or age group-related comparisons. Main results: The patterns and rates of injury differed markedly by activity and study design. Most studies were case-series investigations providing little useful information on risk factors. Intrinsic risk factors included: lower ability, younger age, past injury, and female sex. Extrinsic risk factors were improper binding adjustment, no helmet, certain slope characteristics, and no wrist guards. The literature on the effect of activity, equipment ownership and lessons on injury risk was equivocal. Conclusions: Suggestions for injury prevention include the use of helmets and wrist guards, participation on appropriate runs for ability level, proper fit and adjustment of bindings and other equipment, and taking lessons with the goal of increasing ability and learning hill etiquette. Many areas requiring further research are identified and discussed. New methodological approaches hold promise in advancing the field of ski and snowboard injury research.
\end{abstract}

Copyright (C) 2005 S. Karger AG, Basel

\section{Introduction}

Skiing is an activity practiced by millions of people in snow-blessed countries. Unfortunately, studies have identified it as one of the leading causes of pediatric sport-related injuries [1-3]. Investigators have also found that skiing produces among the most severe sports-related injuries in children [4-6]. Indeed, it was argued long ago that skiing might simply be too difficult a sport for children given the speeds and forces involved [7]. 
Snowboarding has been gaining popularity at the expense of skiing, in particular, among the younger set. The rise in popularity, however, has meant that snowboarding is now labeled as an emerging injury-producing sportrelated activity in children and adolescents [2]. There is evidence that snowboarding injury rates are among the highest of sports-related injury rates in the 9-19-year-old age group [8]. Only by examining the patterns of, and risk factors for, injury in skiing and snowboarding can we identify and target preventive strategies.

The literature on the patterns, incidence, and risk factors for skiing and snowboarding injuries in children and adolescents was reviewed. The search was restricted to English language articles. Medline, SPORTDiscus, Cumulative Index to Nursing and Allied Health Literature, Current Contents, and HealthSTAR were searched using the medical subject headings of Sports, Athletic Injuries, and Accidents. Keywords used within these headings were Skiing and/or Snowboarding. The Ski Trauma and Skiing Safety Series published by the American Society for Testing and Materials was also reviewed. Each title was searched manually for any with a focus on children, adolescents, youth, students, or age group-related comparisons. The reference lists of selected articles were searched using the same criteria.

Most reports are case-series investigations where the characteristics of a series of individuals who were injured in a given activity (e.g., skiing) are detailed. These investigations allow for a comprehensive account of the types of injuries seen, but don't allow calculation of incidence rates or the identification of risk factors unless denominator data (e.g., ski or snowboard lift-tickets) are available. Most studies that do allow for the calculation of risk factors are case-control studies. These studies use a case-series as well as a denominator series (i.e., controls). Many of these studies, however, fail to adjust fully for factors that likely influence crude associations (i.e., the proportion of a given characteristic in the 'case' group is compared with the proportion in the 'control' group). The only information typically available on incidence of injury is based on a denominator of lift-ticket sales (i.e., injuries per 1,000 tickets or visits), which does not account for the differential participation that can occur with the purchase of a single lift-ticket. These issues aside, there are some wellconducted studies we can use to draw from in terms of describing the patterns, rates, and risk factors in these activities for the pediatric age group.

\section{Incidence of Injuries}

The incidence of injury in skiing and snowboarding is largely a function of the injury definition and the nature of the study design. For example, 
if the numerator of a rate is based on a more severe injury definition (e.g., admission to hospital), it will be lower than if it is based on a more inclusive injury definition (e.g., ski patrol reports). In addition, studies of closed or cohort populations (e.g., an enumerated list of skiers followed over a ski season), with less chance of missed injuries compared with studies that rely on injury reporting to a particular care provider (e.g., ski patrol or emergency department), will also contribute to a larger numerator and result in a higher rate.

A comparison of injury rates reported in retrospective cohort, case-control, and case-series studies is shown in table 1 [9-20]. Most rates are calculated as injuries per skier days of participation, although some use runs [9], hours [20] or participants per year [15] for a denominator. Garrick and Requa [13, 18] report the highest injury rate of 9.1 injuries per 1,000 skier days in their cohort study of ski injuries in children and youth. Estimates from case-control and case-series studies are typically much lower ranging from 2.86 to 6.6 injuries per 1,000 skier days $[10,12,14,19]$. Although the higher rates reported in the cohort studies may be due to the earlier time period or the more inclusive injury definition (i.e., self-reported injuries interfering with work or recreation for at least one day), it is likely as much a function of more complete case capture.

Using lift-ticket-based denominators and ski patrol-reported injuries in their case-series investigation, Cadman and Macnab and colleagues [11, 17] determined the incidence of injury in those under the age of 18. In skiers and snowboarders combined, the incidence of injury was 3.8/1,000 visits in those under 7, 4.8/1,000 visits in those between 7-12, and 4.4/1,000 visits in those between 13-17. Again, the more inclusive injury definition and the fact that the rates were for skiers and snowboarders combined may be the reason for the slightly higher rates compared with Deibert et al. [12].

Finally, the data from the study by Hagel et al. [15] indicate a rate of 0.6 injuries per 1,000 participants per year for skiers based on emergency department records for 12-17-year-olds.

There are only two investigations that provide incidence estimates specifically for child and adolescent snowboarders. Based on emergency department data, the study by Hagel et al. [15] indicates a rate of 1.8 per 1,000 snowboarders per year for 12-17-year-olds. In their retrospective cohort study based on medically reported injuries, Machold et al. [16] found the incidence of injury to be 15 per 1,000 snowboard days for all injuries and 10.6/1,000 days for medically treated injuries. It is likely that it is the study of a closed population (i.e., cohort), with more complete case capture, that is driving the higher rate in the Machold et al. [16] study compared with the study by Hagel et al. [15]. 
Table 1. Incidence of injury in skiers and snowboarders

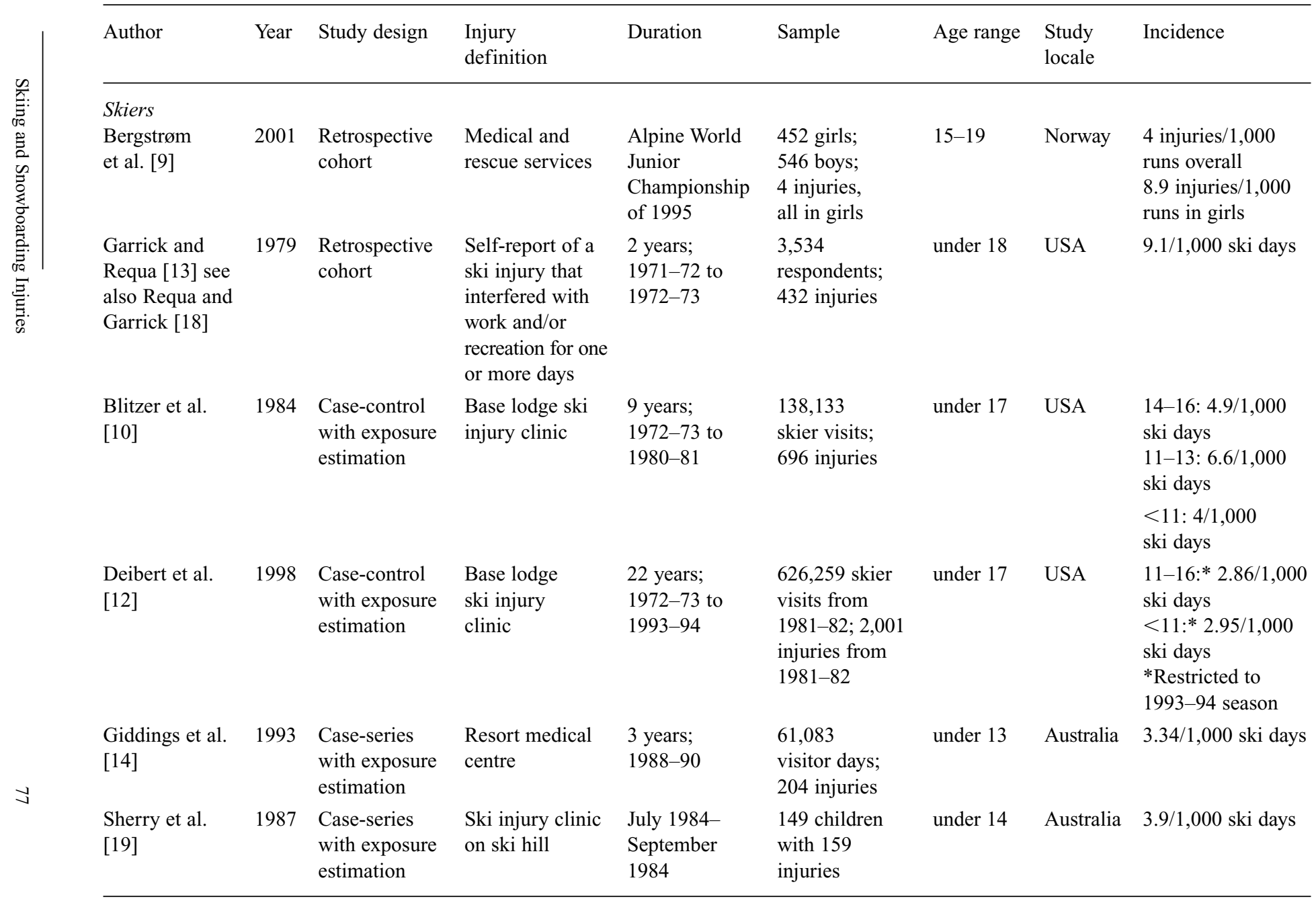


Table 1 (continued)

\begin{tabular}{|c|c|c|c|c|c|c|c|c|}
\hline Author & Year & Study design & $\begin{array}{l}\text { Injury } \\
\text { definition }\end{array}$ & Duration & Sample & Age range & $\begin{array}{l}\text { Study } \\
\text { locale }\end{array}$ & Incidence \\
\hline $\begin{array}{l}\text { Hagel et al. } \\
\text { [15] }\end{array}$ & 2003 & $\begin{array}{l}\text { Case-control/ } \\
\text { Case-series } \\
\text { with exposure } \\
\text { estimation }\end{array}$ & $\begin{array}{l}\text { Emergency } \\
\text { department }\end{array}$ & 1991-99 & $\begin{array}{l}1,114,000 \\
\text { estimated } \\
\text { participants; } \\
669 \text { injuries }\end{array}$ & $12-17$ & Canada & $\begin{array}{l}0.6 / 1,000 \\
\text { skiers per year* } \\
* \text { Rate based on } \\
1997-98 \text { data }\end{array}$ \\
\hline $\begin{array}{l}\text { Wyatt and } \\
\text { Beattie [20] }\end{array}$ & 1995 & $\begin{array}{l}\text { Case-series } \\
\text { with exposure } \\
\text { estimation }\end{array}$ & $\begin{array}{l}\text { Emergency } \\
\text { department }\end{array}$ & $\begin{array}{l}\text { July } 1992- \\
\text { June } 1993\end{array}$ & $\begin{array}{l}116 \text { injuries in } \\
112 \text { patients } \\
\text { on an artificial } \\
\text { ski slope }\end{array}$ & under 13 & Scotland & $1 / 394 \mathrm{~h}$ \\
\hline \multicolumn{9}{|c|}{ Skiers-Snowboarders combined } \\
\hline $\begin{array}{l}\text { Cadman and } \\
\text { Macnab [11], } \\
\text { see also } \\
\text { Macnab et al. } \\
{[17]}\end{array}$ & 1996 & $\begin{array}{l}\text { Case-series } \\
\text { with exposure } \\
\text { estimation }\end{array}$ & Ski patrol reports & $\begin{array}{l}\text { 1991-92 ski } \\
\text { season }\end{array}$ & $\begin{array}{l}142,098 \\
\text { ski visits; } \\
632 \text { skier and } \\
\text { snowboarder } \\
\text { injuries }\end{array}$ & under 17 & Canada & $\begin{array}{l}\text { 13-17: } 4.35 / 1,000 \\
\text { ski-snowboard days } \\
\text { 7-12: } 4.75 / 1,000 \\
\text { ski-snowboard days } \\
0-6: 3.81 / 1,000 \\
\text { ski-snowboard days }\end{array}$ \\
\hline \multicolumn{9}{|l|}{ Snowboarders } \\
\hline $\begin{array}{l}\text { Machold et al. } \\
{[16]}\end{array}$ & 2000 & $\begin{array}{l}\text { Retrospective } \\
\text { cohort }\end{array}$ & $\begin{array}{l}\text { Self-reported } \\
\text { snowboard } \\
\text { days; medically } \\
\text { reported injuries }\end{array}$ & 1996-97 & $\begin{array}{l}2,579 \text { students } \\
\text { reported } 20,238 \\
\text { snowboard } \\
\text { half-days and } \\
152 \text { injuries }\end{array}$ & $\begin{array}{l}\text { Students } \\
\text { from } \\
\text { Austrian } \\
\text { schools } \\
\text { (mean age } \\
=14.7 \text { ) }\end{array}$ & Austria & $\begin{array}{l}\text { All injuries: } \\
15.0 / 1,000 \\
\text { snowboard days } \\
\text { Medically treated: } \\
10.6 / 1,000 \\
\text { snowboard days }\end{array}$ \\
\hline $\begin{array}{l}\text { Hagel et al. } \\
{[15]}\end{array}$ & 2003 & $\begin{array}{l}\text { Case-control/ } \\
\text { Case-series } \\
\text { with exposure } \\
\text { estimation }\end{array}$ & $\begin{array}{l}\text { Emergency } \\
\text { department }\end{array}$ & 1991-99 & $\begin{array}{l}801,000 \\
\text { estimated } \\
\text { participants; } \\
1,436 \text { injuries }\end{array}$ & $12-17$ & Canada & $\begin{array}{l}1.8 / 1,000 \text { snow- } \\
\text { boarders per year* } \\
\text { * Rate based on } \\
1997-98 \text { data }\end{array}$ \\
\hline
\end{tabular}




\section{Injury Characteristics}

Depending on the injury definition, and other characteristics of the study and the participants, large differences in the profile of injuries can result. Table 2 details the burden of injury to particular body regions for child and adolescent skiers and snowboarders [10-12, 14-32]. This is important information for those hoping to implement targeted injury prevention initiatives.

\section{Skiers}

Most injuries that occur in child and adolescent skiers involve the lower extremity. Specifically, study results consistently show that knee and lower leg injuries, in the youngest age groups in particular, are the most common injuries that occur in skiers $[12,14,17-19,24-27,32]$. These injuries are largely due to the lower extremity torsion mechanism in skiing. However, there may be large differences in the proportion of body region-specific injuries depending on both participant and study characteristics.

\section{Head and Spinal Injuries}

Depending on the injury definition, age, and sex of the group, head injuries account for between 5\% [22] and 51.5\% [29] of injuries in skiers. Neck and spinal injuries make up between 2.9 and $7.7 \%$ [12, 15, 29, 31].

Based on ski patrol-reported injuries, Heir et al. [25] found that head injuries represented $17.1 \%$ of all injuries in those under 13 and $19.6 \%$ in those 13-19. The study by Cadman and Macnab [11] found higher proportions of head and face injuries in male skiers (19.3-46.2\%) compared with females (13.4-16.7\%) under 17 [11]. Other ski patrol report-based investigations used injury definitions that do not facilitate comparisons between studies $[23,24]$.

Perhaps surprisingly, the proportion of head injuries is generally lower in those studies using a resort-based medical clinic injury definition. Ekeland et al. [22] found that skier head injuries represented $18 \%$ in those $10-14$ but only $5 \%$ in those under 10. Other investigations using similar definitions have found that the proportion of head injuries falls between the extremes in the Ekeland study ranging from 6 to $14.1 \%$ [10, 12, 14, 19, 27, 32]. A possible reason for the lower proportion of head injuries in these studies compared with the studies based on ski patrol reports is likely to be due to their exclusion of very minor injuries such as contusions and abrasions. This was explicitly stated in the study by Blitzer et al. [10]. 
Table 2. A percent comparison of injury location in skiers and snowboarders

\begin{tabular}{|c|c|c|c|c|c|c|c|}
\hline Study & $\begin{array}{l}\text { Study } \\
\text { design }\end{array}$ & $\begin{array}{l}\text { Data } \\
\text { source }\end{array}$ & $\begin{array}{l}\text { Number of } \\
\text { participants }\end{array}$ & $\begin{array}{l}\text { Age of } \\
\text { participants }\end{array}$ & $\begin{array}{l}\text { Head/Face/ } \\
\text { Spine }\end{array}$ & $\begin{array}{l}\text { Upper } \\
\text { extremity }\end{array}$ & $\begin{array}{l}\text { Lower } \\
\text { extremity }\end{array}$ \\
\hline \multicolumn{8}{|l|}{ Skiers } \\
\hline \multirow{14}{*}{$\begin{array}{l}\text { Cadman } \\
\text { and Macnab } \\
\text { [11], see } \\
\text { also Macnab } \\
\text { et al. [17] }\end{array}$} & \multirow{14}{*}{$\begin{array}{l}\text { Case- } \\
\text { series }\end{array}$} & \multirow{14}{*}{$\begin{array}{l}\text { Ski patrol } \\
\text { reports }\end{array}$} & \multirow{14}{*}{$\begin{array}{l}632 \text { skier and } \\
\text { snowboarder } \\
\text { injuries; } \\
142,098 \text { visits } \\
\text { (number of } \\
\text { injuries in } \\
\text { each activity } \\
\text { not available } \\
\text { from report) }\end{array}$} & \multirow[t]{14}{*}{ Under 17} & Head and face* & Shoulder* & Knee* \\
\hline & & & & & Males: & Males: & Males: \\
\hline & & & & & $13-17: 27.3 \%$ & $13-17: 10.5 \%$ & $13-17: 16.3 \%$ \\
\hline & & & & & $7-12: 19.3 \%$ & $7-12: 4.6 \%$ & $7-12: 16.5 \%$ \\
\hline & & & & & $0-6: 46.2 \%$ & $0-6: 7.7 \%$ & $0-6: 23.1 \%$ \\
\hline & & & & & Head and face:* & Shoulder:* & Knee* \\
\hline & & & & & Females: & Females: & Females: \\
\hline & & & & & $13-17: 15.5 \%$ & $13-17: 3.1 \%$ & $13-17: 33.3 \%$ \\
\hline & & & & & $7-12: 13.4 \%$ & $7-12: 4.1 \%$ & $7-12: 29.9 \%$ \\
\hline & & & & & $0-6: 16.7 \%$ & $0-6: 0 \%$ & $0-6: 16.7 \%$ \\
\hline & & & & & *Differences & *Differences between & *Differences \\
\hline & & & & & $\begin{array}{l}\text { between males } \\
\text { and females }\end{array}$ & $\begin{array}{l}\text { males and females } \\
\text { statistically }\end{array}$ & $\begin{array}{l}\text { between males } \\
\text { and females }\end{array}$ \\
\hline & & & & & statistically & significant $(\mathrm{p}<0.05)$ & statistically \\
\hline & & & & & $\begin{array}{l}\text { significant } \\
(\mathrm{p}<0.05)\end{array}$ & & $\begin{array}{l}\text { significant } \\
(p<0.05)\end{array}$ \\
\hline \multirow{3}{*}{$\begin{array}{l}\text { Goulet et al. } \\
\text { [23] }\end{array}$} & \multirow{3}{*}{$\begin{array}{l}\text { Case- } \\
\text { control }\end{array}$} & \multirow{3}{*}{$\begin{array}{l}\text { Ski patrol } \\
\text { reports }\end{array}$} & \multirow{3}{*}{$\begin{array}{l}41 \text { injured; } \\
346 \text { controls }\end{array}$} & \multirow[t]{3}{*}{ Under 13} & Head and neck: & Upper limb: 14.63 & Lower body: \\
\hline & & & & & $9.76 \%$ & & $63.42 \%$ \\
\hline & & & & & Trunk: $12.19 \%$ & & \\
\hline \multirow{6}{*}{$\begin{array}{l}\text { Hagel et al. } \\
\text { [24] }\end{array}$} & \multirow{6}{*}{$\begin{array}{l}\text { Case- } \\
\text { series }\end{array}$} & \multirow{6}{*}{$\begin{array}{l}\text { Ski patrol } \\
\text { reports }\end{array}$} & \multirow[t]{6}{*}{832 injured } & \multirow[t]{6}{*}{ Under 18} & Females & Females & Females \\
\hline & & & & & Head/neck/ & Upper extremity: & Lower extremity: \\
\hline & & & & & back: $23.7 \%$ & $19.5 \%$ & $53.6 \%$ \\
\hline & & & & & Males & Males & Males \\
\hline & & & & & Head/neck/ & Upper extremity: & Lower extremity: \\
\hline & & & & & back: $35.5 \%$ & $21.3 \%$ & $39.1 \%$ \\
\hline
\end{tabular}




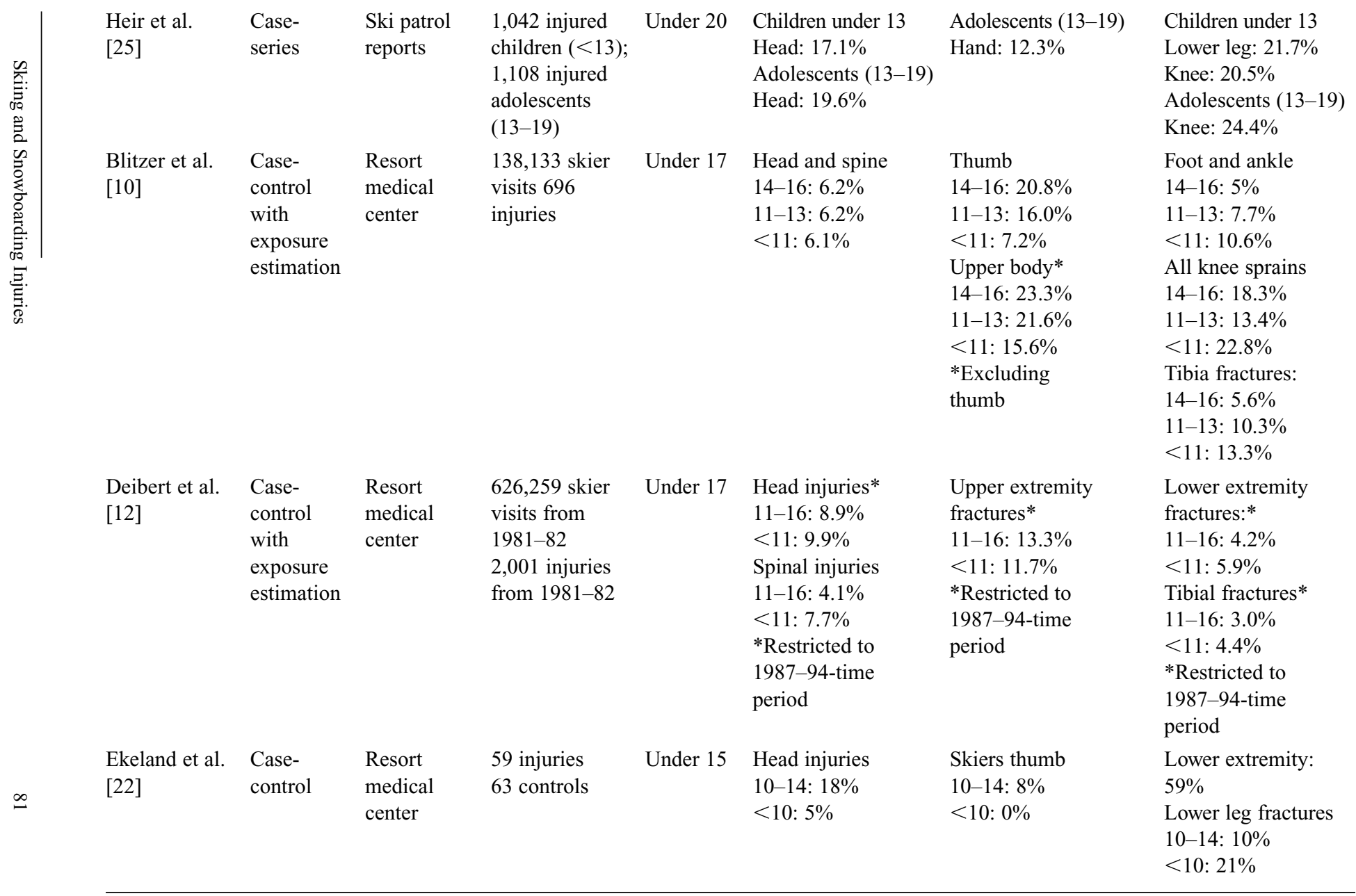


Table 2 (continued)

\begin{tabular}{|c|c|c|c|c|c|c|c|}
\hline Study & $\begin{array}{l}\text { Study } \\
\text { design }\end{array}$ & $\begin{array}{l}\text { Data } \\
\text { source }\end{array}$ & $\begin{array}{l}\text { Number of } \\
\text { participants }\end{array}$ & $\begin{array}{l}\text { Age of } \\
\text { participants }\end{array}$ & $\begin{array}{l}\text { Head/Face/ } \\
\text { Spine }\end{array}$ & $\begin{array}{l}\text { Upper } \\
\text { extremity }\end{array}$ & $\begin{array}{l}\text { Lower } \\
\text { extremity }\end{array}$ \\
\hline $\begin{array}{l}\text { Giddings et al. } \\
\text { [14] }\end{array}$ & Case-series & $\begin{array}{l}\text { Resort } \\
\text { medical } \\
\text { center }\end{array}$ & $\begin{array}{l}61,083 \text { visitor } \\
\text { days and } 204 \\
\text { injuries }\end{array}$ & Under 13 & $\begin{array}{l}\text { Head and face:* } \\
14.1 \% \\
\text { Neck and back: } 3.6 \% \\
\text { Trunk: } 2.3 \% \\
\text { *Significantly } \\
(\mathrm{p}<0.05) \text { more } \\
\text { than } 13 \text { and older }\end{array}$ & $\begin{array}{l}\text { Upper limb: } \\
15.4 \%\end{array}$ & $\begin{array}{l}\text { Lower body:* } \\
64.1 \% \\
\text { *Significantly } \\
(\mathrm{p}<0.01) \text { more } \\
\text { than } 13 \text { and older }\end{array}$ \\
\hline $\begin{array}{l}\text { Molinari et al. } \\
{[27,28]}\end{array}$ & Case-series & $\begin{array}{l}\text { 'Traumato- } \\
\text { logical first } \\
\text { aid post' }\end{array}$ & $\begin{array}{l}587 \text { injuries } \\
\text { in children }\end{array}$ & Under 15 & $\begin{array}{l}\text { Head and face: } \\
13.28 \% \\
\text { Chest and } \\
\text { abdomen: } 1.02 \%\end{array}$ & $\begin{array}{l}\text { Upper limb } \\
\text { including } \\
\text { shoulder: } 42.25 \%\end{array}$ & $\begin{array}{l}\text { Lower limb } \\
\text { including leg: } \\
43.45 \%\end{array}$ \\
\hline $\begin{array}{l}\text { Sherry et al. } \\
{[19]}\end{array}$ & Case-series & $\begin{array}{l}\text { Resort } \\
\text { medical } \\
\text { center }\end{array}$ & $\begin{array}{l}149 \text { children } \\
\text { with } 159 \\
\text { injuries }\end{array}$ & Under 14 & $\begin{array}{l}\text { Head and face: } \\
13 \% \\
\text { Neck and back: } 7 \% \\
\text { Trunk: } 1 \%\end{array}$ & $\begin{array}{l}\text { Upper extremity: } \\
11 \%\end{array}$ & $\begin{array}{l}\text { Lower extremity: } \\
66 \%\end{array}$ \\
\hline $\begin{array}{l}\text { Ungerholm } \\
\text { et al. [32] }\end{array}$ & Case-series & $\begin{array}{l}\text { Resort } \\
\text { medical } \\
\text { center }\end{array}$ & 890 injuries & Under 16 & $\begin{array}{l}\text { Head: } 11.2 \% \\
\text { Trunk: } 3.0 \%\end{array}$ & $\begin{array}{l}\text { Upper extremity: } \\
22.5 \%\end{array}$ & $\begin{array}{l}\text { Lower extremity: } \\
63.3 \%\end{array}$ \\
\hline $\begin{array}{l}\text { Hagel et al. } \\
{[15]}\end{array}$ & $\begin{array}{l}\text { Case- } \\
\text { control/ } \\
\text { Case-series } \\
\text { with } \\
\text { exposure } \\
\text { estimation }\end{array}$ & $\begin{array}{l}\text { Emergency } \\
\text { department }\end{array}$ & 6,441 & Under 18 & $\begin{array}{l}\text { Head (including } \\
\text { brain and face): } \\
13.1 \% \\
\text { Neck: } 2.9 \%\end{array}$ & Not available & Not available \\
\hline Hill [26] & Case-series & $\begin{array}{l}\text { Emergency } \\
\text { department }\end{array}$ & $\begin{array}{l}8 \text { injuries on } \\
\text { snow slopes; } \\
8 \text { injuries on } \\
\text { dry slopes }\end{array}$ & Under 16 & Head/neck/face: $0 \%$ & Upper limb: $37.5 \%$ & $\begin{array}{l}\text { Lower limb: } 62.5 \% \\
\text { Tibia fracture: } \\
37.5 \%\end{array}$ \\
\hline
\end{tabular}




\begin{tabular}{|c|c|c|c|c|c|c|c|}
\hline $\begin{array}{l}\text { Waytt and } \\
\text { Beattie. [20] }\end{array}$ & Case-series & $\begin{array}{l}\text { Emergency } \\
\text { department }\end{array}$ & $\begin{array}{l}116 \text { injuries } \\
\text { in } 112 \\
\text { patients on } \\
\text { an artificial } \\
\text { ski slope }\end{array}$ & Under 13 & Head injuries: $2.6 \%$ & Not available & Not available \\
\hline $\begin{array}{l}\text { Shorter et al. } \\
\text { [29] }\end{array}$ & Case-series & $\begin{array}{l}\text { Admission } \\
\text { to a } \\
\text { pediatric } \\
\text { trauma } \\
\text { centre }\end{array}$ & $\begin{array}{l}68 \text { injuries in } \\
38 \text { patients }\end{array}$ & Under 19 & $\begin{array}{l}\text { Head and face: } \\
51.5 \% \text { of injuries } \\
71.0 \% \text { of patients } \\
\text { Trunk: } \\
16.2 \% \text { of injuries } \\
29.0 \% \text { of patients } \\
\text { Spinal: } \\
2.9 \% \text { of injuries } \\
5.3 \% \text { of patients }\end{array}$ & Not available & Not available \\
\hline $\begin{array}{l}\text { Skokan et al. } \\
\text { [31] }\end{array}$ & Case-series & $\begin{array}{l}\text { Admission } \\
\text { to a } \\
\text { pediatric } \\
\text { trauma } \\
\text { centre }\end{array}$ & 101 patients & Under 18 & $\begin{array}{l}\text { Head-face: } 33 \% \\
\text { Spine: } 5 \% \\
\text { Trunk: } 17 \%\end{array}$ & $\begin{array}{l}\text { Upper extremity: } \\
8 \%\end{array}$ & $\begin{array}{l}\text { Lower extremity: } \\
22 \%\end{array}$ \\
\hline $\begin{array}{l}\text { Requa and } \\
\text { Garrick [18] }\end{array}$ & $\begin{array}{l}\text { Retro- } \\
\text { spective } \\
\text { cohort }\end{array}$ & $\begin{array}{l}\text { Self-report } \\
\text { of injuries } \\
\text { interfering } \\
\text { with work } \\
\text { or } \\
\text { recreational } \\
\text { activities for } \\
\text { one or more } \\
\text { days }\end{array}$ & $\begin{array}{l}431 \text { injuries } \\
\text { in } 3,534 \\
\text { skiers }\end{array}$ & Under 20 & $\begin{array}{l}\text { 3-13 age group } \\
\text { Head/neck: } 7.1 \% \\
\text { 14-19 age group } \\
\text { Head/neck: } 6.5 \%\end{array}$ & $\begin{array}{l}3-13 \text { age group } \\
\text { Upper extremity: } \\
14.8 \% \\
14-19 \text { age group } \\
\text { Upper extremity: } \\
14.6 \%\end{array}$ & $\begin{array}{l}3-13 \text { age group } \\
\text { Lower extremity: } \\
69.8 \% \\
14-19 \text { age group } \\
\text { Lower extremity: } \\
72.1 \%\end{array}$ \\
\hline
\end{tabular}


Table 2 (continued)

\begin{tabular}{|c|c|c|c|c|c|c|c|}
\hline Study & $\begin{array}{l}\text { Study } \\
\text { design }\end{array}$ & $\begin{array}{l}\text { Data } \\
\text { source }\end{array}$ & $\begin{array}{l}\text { Number of } \\
\text { participants }\end{array}$ & $\begin{array}{l}\text { Age of } \\
\text { participants }\end{array}$ & $\begin{array}{l}\text { Head/Face/ } \\
\text { Spine }\end{array}$ & $\begin{array}{l}\text { Upper } \\
\text { extremity }\end{array}$ & $\begin{array}{l}\text { Lower } \\
\text { extremity }\end{array}$ \\
\hline $\begin{array}{l}\text { Snowboarders } \\
\text { Cadman and } \\
\text { Macnab [11], } \\
\text { see also } \\
\text { Macnab et al. } \\
\text { [17] }\end{array}$ & Case-series & $\begin{array}{l}\text { Ski patrol } \\
\text { reports }\end{array}$ & $\begin{array}{l}632 \text { skier and } \\
\text { snowboarder } \\
\text { injuries; } \\
142,098 \text { visits } \\
\text { (number of } \\
\text { injuries in each } \\
\text { activity not } \\
\text { available from } \\
\text { report) }\end{array}$ & Under 17 & $\begin{array}{l}\text { Head and face } \\
\text { Males: } \\
\text { 13-17: } 9.3 \% \\
\text { 7-12: } 0 \\
0-6: 0 \\
\text { Head and face } \\
\text { Females: } \\
\text { 13-17: } 20.8 \% \\
7-12: 50.0 \% \\
0-6: 0\end{array}$ & $\begin{array}{l}\text { Shoulder } \\
\text { Males: } \\
\text { 13-17: } 2.4 \% \\
\text { 7-12: } 25.0 \% \\
\text { 0-6: 0 } \\
\text { Shoulder } \\
\text { Females: } \\
\text { 13-17: } 0 \\
\text { 7-12: } 0 \\
0-6: 0 \\
\text { Wrist } \\
\text { Males: } \\
\text { 13-17: 47.62\% } \\
\text { 7-12: } 25.0 \% \\
0-6: 0 \\
\text { Wrist } \\
\text { Females: } \\
\text { 25.0\% } \\
\text { 13-17: } \\
\text { 7-12: } 0 \\
0-6: 0\end{array}$ & $\begin{array}{l}\text { Knee } \\
\text { Males: } \\
\text { 13-17: } 11.9 \% \\
\text { 7-12: } 37.5 \% \\
\text { 0-6: 0 } \\
\text { Knee } \\
\text { Females: } \\
\text { 13-17: } 29.2 \% \\
\text { 7-12: } 50.0 \% \\
0-6: 0\end{array}$ \\
\hline $\begin{array}{l}\text { Hagel et al. } \\
\text { [24] }\end{array}$ & Case-series & $\begin{array}{l}\text { Ski patrol } \\
\text { reports }\end{array}$ & 557 injured & Under 18 & $\begin{array}{l}\text { Females } \\
\text { Head/neck/back: } \\
18.3 \% \\
\text { Males } \\
\text { Head/neck/ } \\
\text { back: } 28.6 \%\end{array}$ & $\begin{array}{l}\text { Females } \\
\text { Upper extremity: } \\
53.7 \% \\
\text { Males } \\
\text { Upper extremity: } \\
46.8 \%\end{array}$ & $\begin{array}{l}\text { Females } \\
\text { Lower extremity: } \\
23.2 \% \\
\text { Males } \\
\text { Lower extremity: } \\
19.1 \%\end{array}$ \\
\hline
\end{tabular}




\begin{tabular}{|c|c|c|c|c|c|c|c|}
\hline $\begin{array}{l}\text { Drkulec and } \\
\text { Letts [21] }\end{array}$ & Case-series & $\begin{array}{l}\text { Emergency } \\
\text { department }\end{array}$ & $\begin{array}{l}118 \text { injuries } \\
\text { in } 113 \\
\text { children }\end{array}$ & Under 19 & $\begin{array}{l}\text { Head injuries: } 8 \% \\
\text { Cervical spine } \\
\text { injuries: } 1.7 \% \\
\text { Abdominal } \\
\text { injuries: } 5 \%\end{array}$ & $\begin{array}{l}\text { Upper extremity: } \\
80 \% * \\
* \text { Distal radius } \\
\text { fractures occurred } \\
\text { in } 53 \text { of } 113 \text { children }\end{array}$ & $\begin{array}{l}\text { Lower extremity: } \\
7 \%\end{array}$ \\
\hline $\begin{array}{l}\text { Hagel et al. } \\
{[15]}\end{array}$ & $\begin{array}{l}\text { Case- } \\
\text { control/ } \\
\text { Case-series } \\
\text { with } \\
\text { exposure } \\
\text { estimation }\end{array}$ & $\begin{array}{l}\text { Emergency } \\
\text { department }\end{array}$ & 3,626 injuries & Under 18 & $\begin{array}{l}\text { Head (including } \\
\text { brain and face): } \\
10.5 \% \\
\text { Neck: } 1.9 \%\end{array}$ & Not available & Not available \\
\hline $\begin{array}{l}\text { Machold et al. } \\
{[16]}\end{array}$ & $\begin{array}{l}\text { Retro- } \\
\text { spective } \\
\text { cohort }\end{array}$ & $\begin{array}{l}\text { Self- } \\
\text { reported } \\
\text { snowboard } \\
\text { days; } \\
\text { medically } \\
\text { reported } \\
\text { injuries }\end{array}$ & $\begin{array}{l}2,579 \text { students } \\
\text { reported } 20,238 \\
\text { snowboard } \\
\text { half-days and } \\
152 \text { injuries }\end{array}$ & $\begin{array}{l}\text { Students } \\
\text { from } \\
\text { Austrian } \\
\text { schools } \\
\text { (mean age } \\
\text { of 14.7) }\end{array}$ & $\begin{array}{l}\text { Head: } 11.2 \% \\
\text { Trunk: } 2.0 \%\end{array}$ & $\begin{array}{l}\text { Upper extremity: } \\
61.1 \% \\
\text { Lower arm/wrist/hand: } \\
51.9 \%\end{array}$ & $\begin{array}{l}\text { Lower extremity: } \\
21.1 \%\end{array}$ \\
\hline $\begin{array}{l}\text { Shorter et al. } \\
{[30]}\end{array}$ & Case-series & $\begin{array}{l}\text { Admission } \\
\text { to a } \\
\text { pediatric } \\
\text { trauma } \\
\text { centre }\end{array}$ & $\begin{array}{l}34 \text { injuries in } \\
27 \text { patients }\end{array}$ & Under 19 & $\begin{array}{l}\text { Head and face: } \\
38.2 \% \text { of injuries } \\
48.1 \% \text { of patients } \\
\text { Trunk: } \\
23.5 \% \text { of injuries } \\
29.6 \% \text { of patients } \\
\text { Cervical spine: } \\
2.9 \% \text { of injuries } \\
3.7 \% \text { of patients }\end{array}$ & Not available & Not available \\
\hline $\begin{array}{l}\text { Skokan et al. } \\
{[31]}\end{array}$ & Case-series & $\begin{array}{l}\text { Admission } \\
\text { to a level } \\
\text { one } \\
\text { pediatric } \\
\text { trauma } \\
\text { centre }\end{array}$ & 101 patients & Under 18 & $\begin{array}{l}\text { Head-face: } 31 \% \\
\text { Spine: } 5 \% \\
\text { Trunk: } 18 \%\end{array}$ & $\begin{array}{l}\text { Upper extremity: } \\
5 \%\end{array}$ & $\begin{array}{l}\text { Lower extremity: } \\
16 \%\end{array}$ \\
\hline
\end{tabular}


Only three studies used a definition of emergency department-reported injuries. Hagel et al. [15] noted that head injuries (including brain and face) made up $13.1 \%$ of emergency department-reported injuries in skiers. Head injuries represented only $2.6 \%$ of all emergency department-reported injuries occurring on artificial ski slopes in those under 13 in the study by Wyatt and Beattie [20], while Hill [26] found no head injuries in their small study of only 16 individuals injured on dry and snow slopes. The study by Hagel et al. [15], the most recent of the three and the only one that focused on snow skiing exclusively, compares to those using a resort-based medical clinic injury definition.

For those most severe injuries requiring admission to a pediatric trauma center, head and face injuries were found to make up between 33\% [31] and $51.5 \%$ [29] of all injuries in young skiers. These data are consistent with the link between injury severity and head injury.

Neck and spinal injuries, which can have life-altering consequences, also afflict skiers. These injuries make up between 2.9 and $7.7 \%$ of the total, depending on the injury definition and age group $[12,15,29,31]$.

Cadman and Macnab [11] put the issue of head and neck injuries in perspective:

Clearly, not all head injuries are severe and only occasionally does spinal injury occur. With head injury rates as high as they are, however, the potential risks of significant injury are considerable and any measures which decrease either the incidence or the severity of head injury, or which prevent even an occasional cervical spine injury, would have major cost and humanitarian benefits.

\section{Upper Extremity Injuries}

As was the case for head and spinal injuries, the injury definition and group characteristics result in a large range of reported upper extremity injuries: $<5 \%$ [11] to $42.3 \%$ [27].

Ski patrol reported upper limb injuries represented $14.6 \%$ of injuries in skiers in the study by Goulet et al. [23], while Hagel et al. [24] found they accounted for $19.5 \%$ in females and $21.3 \%$ in males based on a similar injury definition. In those under 17, Cadman and Macnab [11] noted a greater proportion of shoulder injuries in males (4.6-10.5\%) compared with females (under 5\%) based on ski patrol reports.

Based on resort medical clinic records, upper extremity injuries account for between 11 and $42.3 \%$ of all injuries [10, 12, 14, 19, 27, 32]. However, excluding the Italian study [27], the range falls to between $11 \%$ [19] and approximately $23 \%[10,32]$. Similarly, upper extremity injuries represented $15 \%$ of the self-reported injuries interfering with work or recreation for at least one day in the study by Requa and Garrick [18]. 
From a study of artificial and natural ski slopes, Hill found that $37.5 \%$ of all emergency department injuries were to the upper limb [26]. Apart from the data presented by Molinari et al. [27], this suggests a higher proportion of upper extremity injuries on artificial slopes.

Upper extremity injuries are not usually part of the spectrum of severe injuries in skiers. Skokan et al. [31] reported that upper limb injuries represented only $8 \%$ of all injuries in those under 18 admitted to a level I pediatric trauma centre.

\section{Lower Extremity Injuries}

The lower extremity has received the most attention in the ski injury literature due to the large portion of injuries that occur to this region. Although there is a large variation from study to study, almost all identify the lower extremity as the most frequently injured body region for skiers with the proportion ranging from $22 \%$ [31] to $72 \%$ [18].

Ski patrol-reported injury data suggest that lower extremity injuries make up between 39.1 and $63.4 \%$ of injuries in young skiers [11,23-25]. These data suggest that lower extremity injuries are more prevalent in females and younger age groups.

Data from resort medical centers suggest that lower extremity injuries represent between 43.5 and $66 \%$ of injuries in young skiers [14, 19, 22, 27, 32]. The investigation of dry and snow slope injuries reported to an emergency department produced similar findings [26], while self-reported injuries interfering with work or recreation for one day or more represented over two thirds of the injuries in the study by Requa and Garrick [18]. As with ski patrol-based studies, these investigations have found an association between younger age and lower limb injury, particularly fractures [10, 12, 22].

As with upper extremity injuries, data based on admissions to a pediatric trauma center indicate that lower extremity injuries are generally less severe. Skokan et al. [31] reported that lower extremity injuries made up only $22 \%$ of all injuries in their pediatric trauma center series.

\section{Snowboarders}

In child and adolescent snowboarders, there is evidence that upper extremity injuries are the main problem. Most studies on child and adolescent snowboarders indicate that the wrist and forearm are most frequently injured in snowboarders due to an upper extremity impact mechanism $[16,21,24,30]$. However, as noted for skiers, the body region distribution of injuries may change based on study and participant characteristics. 


\section{Head and Spinal Injuries}

Head injuries represent between $8 \%$ of injuries to those under 19 based on emergency department records [21] to $50 \%$ in females aged 7-12 years based on ski patrol reports [11]. Based on admission to a pediatric trauma center, cervical spine injuries represent $2.9 \%$ of all injuries in those under 19 [30] while all spinal injuries make up 5\% of the total injuries in those admitted under age 18 [31].

Ski patrol-reported head and face injuries combined represented $9.3 \%$ of injuries in males $13-17,20.8 \%$ in females $13-17$, and $50 \%$ in females $7-12$ in the study by Cadman and Macnab [11]. No males under age 13 sustained a ski patrol-reported head injury in the Cadman and Macnab study. Snowboarder head, neck, and back injuries combined represented $18 \%$ in females, but almost $29 \%$ in males under 18 in the study by Hagel et al. [24].

From emergency department reports, head injuries accounted for between 8 and $10.5 \%$ of all injuries in young snowboarders $[15,21]$. This is similar to the $11.2 \%$ head injuries found by Machold et al. [16] based on medically treated injuries in student snowboarders.

As was the case for skiers, the greater the injury severity, the more likely the head was involved. For injuries requiring admission to a pediatric trauma center, head and face injuries combined represented $38.2 \%$ of injuries in the study by Shorter et al. [30]. This is similar to the 31\% found by Skokan et al. [31] using a similar injury definition.

Although the proportion of neck and spinal injuries in child and adolescent snowboarders is relatively small, ranging from $1.9 \%$ based on emergency department reports to $5 \%$ based on admission to a pediatric trauma center, these injuries can be severe and there are indications of a trend with injury severity $[15,30,31]$.

\section{Upper Extremity Injuries}

Whereas the lower extremity represented the largest problem for child and adolescent skiers, the upper extremity is the body region of injury for most snowboarders. Upper extremity injuries represent between $46.8 \%$ of ski patrolreported injuries in males under age 17 [24] to $80 \%$ of all injuries based on emergency department records [21]. Forearm and wrist injuries are by far the most common problem $[11,16,21]$. However, only $5 \%$ of admissions to a pediatric trauma center involved injuries to the upper extremity reflecting their importance in terms of frequency, but not necessarily severity [31].

\section{Lower Extremity Injuries}

Lower extremity injuries in snowboarders do not represent the same problem in snowboarders as they do in skiers. Lower extremity injuries account for $16 \%$ of all injuries in snowboarders admitted to a pediatric trauma center [31], $21.1 \%$ of medically treated snowboard injuries [16], and between 19.1 and 
$23.2 \%$ of ski patrol-reported injuries [24]. However, these injuries represent only $7 \%$ of all injuries based on emergency department records [21].

\section{Time Trends}

Deibert et al. [12] examined time trends in skiing injury rates from the 1971-72 through 1993-94 time period. They found that the rate of all lower extremity fractures, and tibial and ankle fractures in particular, decreased significantly in those under age 17. Similarly the rate of skull fractures in children under 11, first and second degree knee sprains and ankle sprains in those under 17, and thumb sprains in those 11-16 also decreased. However, the rate of spinal injuries in the 11-16-year age group increased significantly. Although not statistically significant, the authors also noted an increase in all head injuries combined for those under 11, and third degree knee anterior cruciate ligament sprains in those between 11-16 years of age.

A Canadian investigation of emergency department-reported injuries in skiers and snowboarders suggest that the rate of brain injuries in adolescent [12-17] skiers increased 2-fold from 1995 through 1999 (Rate ratio: 1.9; 95\% CI: 1.1-3.3). In snowboarders, the rate of head (Rate ratio: 1.58; 95\% CI: 1.07-2.34) and neck (Rate ratio: 3.37; 95\% CI: 1.6-7.3) injuries increased over the 4-year period [15].

\section{Characteristics of the Injury Event}

The circumstances surrounding the injury event are important to consider. Although an assessment of risk is not available from only an injured series, identification of prevalent event-related characteristics provides the basis for analytic studies aimed at evaluating potential causative factors.

\section{Competition versus Practice}

The majority of injuries occur during recreational participation in skiing (66.7\%) and snowboarding (74.7\%) [24]. Only a small proportion of skiers [24, 29] and snowboarders [24] are injured during training or competition. However, this may simply reflect the greater number of recreational participants, rather than a relation with injury risk.

Time of Day

In terms of the time of day of injury, investigations are inconsistent. Some suggest the majority of injuries occur in the afternoon and evening [24, 29], others mid-morning and afternoon $[16,30]$. 
The results, at least for lower extremity injuries in skiers, do not support fatigue as the main cause of injury. Specifically, Ungerholm et al. [32] found that over $70 \%$ of lower extremity-injured skiers were participating for $2 \mathrm{~h}$ or less at the time of the event.

\section{Time of Season}

Most injuries in skiers and snowboarders occur during the heart of the winter season (i.e., January and February in the northern hemisphere) [21, 24, 29], no doubt a reflection of greater participation during this time.

Depending on the activity and the type of injury, a large proportion (67-83\%) of skier and snowboarder injuries occur within the first week [16,33], with estimates of between $3.5 \%$ [16] and almost $25 \%$ [24, 29] the first day. For lower extremity-injured skiers, Ungerholm and Gustavsson [33] found that $83 \%$ had been skiing for one week or less. These same authors noted that in those with a lower leg fracture, $19 \%$ were in their first season [34].

\section{Mechanism of Injury}

The primary mechanisms of injury in both skiers and snowboarders are falls and collisions. However, falls are more prevalent among injured snowboarders. The difficulty in summarizing the literature is that it is generally inconsistent in categorization. For example, some investigators include jumping in the falls category [30].

\section{Skiers}

The dominant mechanism of injury in skiers is a fall accounting for $43-76 \%$ of injuries [20, 22, 31]. Ungerholm et al. [34] noted that $93 \%$ of children under 16 with lower leg fractures reported the injury event only involved them.

Collisions account for between 11 and 58\% [19, 20, 22, 24, 27-29, 31]. Generally, as the severity of the injury definition increases, so too does the proportion of collision-related injuries with between $29 \%$ [31] and $58 \%$ [29] of hospital-admitted patients reporting this mechanism, primarily with trees. Restricting the injured body region to the lower extremity decreases the proportion of collision-related injuries [33, 34]. Intermediate skiers report a lower proportion of collision-related injuries than do experts or beginners [29].

Lift-related injuries in skiers account for 5-18\% [20, 22, 24, 31], while jumping accounts for less than $7 \%[24,31]$.

Skiers and Snowboarders

For skiers and snowboarders combined, the primary mechanism was personal error $(0-6$ years $=43 \% ; 7-12=57 \% ; 13-17=59 \%)$. The second most common mechanism changed depending on the age group. In those $0-6$ years 
it was collision with an object (17\%), jumping in 13-17-year-olds (12\%), while those $7-12$ 'cited change in snow conditions, collisions with objects, jumping, and human collisions equally frequently (8\%)’ [17].

\section{Snowboarders}

Falls are by far the main mechanism of injury in snowboarders accounting for between 69 and $93 \%$ of injuries [16, 21, 30, 31]. In their study, Machold et al. [16] suggest that 'The primary mechanism of injury was through low-velocity falls on hard or icy snow...' Collisions make up only $4-26 \%$ of snowboarding injuries $[21,24,30,31]$. As for skiers, with increasing injury severity, the proportion of injuries involving collisions also increases [30, 31].

Hagel et al. [24] noted $10.1 \%$ of jumping-related and $6 \%$ of lift-related injuries in snowboarders reporting injuries to the ski patrol. However, Skokan et al. [31] found no jumping- or lift-related injuries in their series of hospitaladmitted snowboarders.

\section{Injury Severity}

Few studies have been conducted on the issue of injury severity in young skiers and snowboarders. Those that have been conducted indicate that these injuries can be severe, as measured by injury severity scales, length of hospital stay, and sequelae, and can have significant associated financial and personal costs.

\section{Injury Type}

As noted earlier, it is evident that head and neck spine injuries represent the most severe injuries in both skiers and snowboarders. This is based on the contrast between those studies with an injury definition of admission to a pediatric trauma center with those requiring less rigorous medical and paramedical intervention. This can also be seen with those studies that focus on a severely injured group of skiers and snowboarders such as those admitted to hospital.

Those investigations focusing on a hospitalized series find high proportions of head injuries and long bone fractures [29-31, 35]. For skiers, head injuries make up between $22 \%$ [31] and $71 \%$ [29] of all injuries requiring hospital admission, whereas long bone fractures represent between 19\% [29] and $32 \%$ [35]. Leg injuries in total account for approximately $39 \%$ of skier injuries requiring hospital admission [31]. 
For hospital-admitted snowboarders, however, the proportion changes where head injuries result in between $35 \%$ [30] and $42 \%$ [31] and long bone fractures account for approximately $35 \%$ [30] of all injuries.

The study by Machold et al. [16] however, based on self-reported medically treated snowboarding injuries suggests a much higher proportion of upper extremity injuries at $65 \%$. This substantial difference indicates how important injury definition can be.

\section{Injury Score/Scale}

Another way to categorize trauma is the Abbreviated Injury Scale (AIS) [36], associated Injury Severity Score (ISS) [37], and Pediatric Trauma Score [38]. However, few studies have used this approach. Those studies that have used this approach report inconsistent results with some suggesting that snowboarders sustain more severe injuries [35], others that skiers do [29, 30], while still others note no activity-related differences [31].

Hackam et al. [35] in their case-series of hospital-admitted children under 17 years for tobogganing, skiing and snowboarding injuries noted the mean ISS [37] was significantly $(\mathrm{p}<0.05)$ higher for snowboarders $(18.3 \pm 2$, one death $)$ compared with skiers $(8.4 \pm 2$ ), and that $44 \%$ of snowboarders, but only $17 \%$ of skiers had an ISS greater than 15 [35].

Machold et al. [16] in studying snowboarding injuries in Austrian students, noted that of 107 injuries requiring medical care, 51.4\% were classified as moderate or severe, not life threatening according to an AIS greater than one [36].

Shorter et al. [29, 30] found better Pediatric Trauma Scores in their series of hospital admitted snowboarders compared with hospital-admitted skiers to age 18 .

Skokan et al. [31] examined winter sports injuries in children admitted to hospital up to age 17. Although there were 4 children injured while snowmobiling or lugeing, $98(96 \%)$ were injured skiing $(\mathrm{n}=72)$ or snowboarding $(\mathrm{n}=26)$. The median ISS was 7 (range 1-75) with no difference among activities. The authors note that almost one third of those requiring hospitalization sustained head injuries and that this group had the highest abbreviated injury scale [39] and ISS along with the longest hospital stays.

\section{Cost}

Few studies have examined the financial costs associated with skiing and snowboarding injuries. Those that have, however, reveal the financial impact of 
hospital admitted injuries can be staggering with direct medical costs ranging from USD 10,000 for snowboarders [30] to USD 28,000 for skiers [35].

Hackam et al. [35] conducted a comprehensive cost-estimate study of children under 17 hospitalized for tobogganing, skiing and snowboarding injuries. Estimated hospital costs were almost USD 28,000 per patient, outpatient services were estimated at USD 15,243 per patient and the financial impact to the family of the victim was assessed at USD 1,500 per patient [35]. These cost estimates are similar to the estimates derived from the case-series study by Shorter et al. [29] noting that the average cost of a skiing injury admitted to a pediatric trauma centre was USD 22,000. In their subsequent study, however, Shorter et al. [30] found an average cost of only USD 10,000 for injured snowboarders admitted to hospital.

\section{Length of Hospital Stay}

In those skiers and snowboarders admitted to hospital, stays range from 1 to 40 days [29-31, 34]. There is some evidence that snowboarders require shorter hospital stays [30].

In their case-series investigation, Shorter et al. [29] found that the average hospital stay for an admitted skier under 17 years of age was 7.3 days (range 1-40). However, in their follow-up study of hospital-admitted snowboarders, the authors noted the average hospital stay was only 3.8 days (range 1-15) [30]. In the study by Skokan et al. [31] the length of hospital stay for skiing, snowboarding, snowmobiling and lugeing combined ranged from 1 to 18 days. Ungerholm et al. [34] followed children under age 16 with lower leg fractures sustained while skiing to determine the duration of convalescence and the nature and extent of sequelae. The median hospital stay was 3.5 days (range 2-16).

\section{Outcome}

Skiing and snowboarding injuries can result in significant long-term sequelae, indeed, even permanent damage and death. With the focus on injury outcome, the investigations considered demonstrate that a significant proportion of hospitalized skiers and snowboarders require intensive care [31], operations and postdischarge support services [35], and can have sequelae ranging from weeks to years [16, 29, 34]. A brief overview of each study is provided below.

Hackam et al. [35] in their case-series of hospital admitted children under 17 years for tobogganing, skiing and snowboarding injuries noted that all admitted patients had life-threatening or serious injuries [35]. Most patients required some 
type of operation (75\%). Almost half of admitted skiers (46\%) and snowboarders (44\%) required either inpatient or outpatient support services after discharge.

Machold et al. [16] found that those Austrian students with moderate and severe injuries reported they were 'incapacitated' for more than 21 days.

In their case-series investigation of injured skiers admitted to hospital, Shorter et al. [29] found that, although there were no deaths in the series, $26 \%$ had long-term sequelae including hearing loss, hemiplegia, paraplegia, and below knee amputation. In their follow-up study, the authors found no deaths among hospital-admitted snowboarders under 17 [30]. These investigators also suggest that the overall severity of injury is lower in snowboarders compared with skiers based on Pediatric Trauma Score [38], length of hospital stay, and cost [30].

Skokan et al. [31] examined winter sports injuries in children admitted to hospital up to age 17 . Three percent of skiers but $12 \%$ of snowboarders required admission to the pediatric intensive care unit, findings at odds with the length of stay and cost estimates of Shorter et al. [29, 30].

Ungerholm et al. [34] followed children under the age of 16 with lower leg fractures sustained while skiing to determine the duration of convalescence and the nature and extent of sequelae. From 1979 through 1982, 113 children reported to the emergency medical offices at two Swedish ski areas. The median duration of ambulatory treatment was 7.5 weeks (range 4-40). Of the 104 patients who answered a questionnaire at 1-3 years follow-up, 97 reported no sequelae, while the remainder reported 'pain on exercise (3), shortening of the leg (2), outward rotation of the foot (1), and angulation of the lower leg (1)' [34]. The median duration of morbidity was 3.5 months (range 1-18 months).

Clearly skiing and snowboarding injuries can be frequent and severe. A proper examination of risk factors with a view to prevention is the only way to mitigate their impact.

\section{Injury Risk Factors}

A number of factors have been shown to influence the risk of injury in skiing and snowboarding. The risk factors are detailed in table 3 [9-14, 16-18, $22,23,31,33,35,40-42]$. Except where indicated, a relative measure of association (e.g., odds ratio) is presented. For example, an odds ratio of 1.5 would indicate a $50 \%$ greater risk of injury in the index category of the determinant (e.g., in the study by Deibert et al. [12], those under 11 years of age) compared with the reference category of the determinant (e.g., in Deibert et al. [12], those 11-16 years old). Alternatively, an odds ratio of 0.5 would indicate a $50 \%$ reduction in injury risk comparing the index with the referent category of the determinant. The reference category of the determinant always has a value of 1.0. 
Table 3. Injury determinants in skiers and snowboarders

\begin{tabular}{|c|c|c|c|c|}
\hline Author & Design & Determinant & \multicolumn{2}{|l|}{ Results } \\
\hline $\begin{array}{l}\text { Skiers } \\
\text { Bergstrøm } \\
\text { et al., 2001 [9] }\end{array}$ & $\begin{array}{l}\text { Prospective } \\
\text { cohort }\end{array}$ & Sex & \multicolumn{2}{|l|}{ No injuries in males; 4 in females } \\
\hline $\begin{array}{l}\text { Blitzer et al., } \\
1984 \text { [10] see also } \\
\text { Deibert et al. [12] }\end{array}$ & $\begin{array}{l}\text { Case-control } \\
\text { with exposure } \\
\text { estimation }\end{array}$ & Age & $\begin{array}{l}\text { All injuries* } \\
\text { 14-16: } \\
\text { 11-13: } \\
<11: \\
\text { Tibial fractures* } \\
\text { 14-16: } \\
\text { 11-13: } \\
<11: \\
\text { Thumb* } \\
\text { 14-16: } \\
\text { 11-13: } \\
<11: \\
\text { *No absolute numbers provided so }\end{array}$ & $\begin{array}{l}4.9 / 1,000 \text { skier days (significantly different } \\
\text { from } 11-13 \text { ) } \\
6.6 / 1,000 \text { skier days } \\
4 / 1,000 \text { skier days (significantly different } \\
\text { from } 11-13 \text { ) } \\
0.27 / 1,000 \text { skier days (significantly different } \\
\text { from } 11-13 \text { ) } \\
0.68 / 1,000 \text { skier days } \\
0.53 / 1,000 \text { skier days } \\
1 / 1,000 \text { skier days } \\
1.1 / 1,000 \text { skier days } \\
0.29 / 1,000 \text { skier days (significantly different } \\
\text { from } 11-13 \text { ) } \\
\text { uld not calculate } 95 \% \text { confidence limits }\end{array}$ \\
\hline $\begin{array}{l}\text { Blitzer et al., } \\
1984 \text { [10] see also } \\
\text { Deibert et al. [12] }\end{array}$ & $\begin{array}{l}\text { Case-control } \\
\text { with exposure } \\
\text { estimation }\end{array}$ & Ability & $\begin{array}{l}\text { Controls had greater skill than mos } \\
\text { (no p value reported) }\end{array}$ & lower extremity-injured groups \\
\hline $\begin{array}{l}\text { Blitzer et al., } \\
1984 \text { [10] see also } \\
\text { Deibert et al. [12] }\end{array}$ & $\begin{array}{l}\text { Case-control } \\
\text { with exposure } \\
\text { estimation }\end{array}$ & $\begin{array}{l}\text { Equipment } \\
\text { ownership }\end{array}$ & $\begin{array}{l}11-16 \text {-year-olds less frequently ow } \\
\text { controls }(\mathrm{p}<0.05)\end{array}$ & ed their equipment compared with \\
\hline
\end{tabular}


Table 3 (continued)

\begin{tabular}{|c|c|c|}
\hline Author & Design & Determina \\
\hline $\begin{array}{l}\text { Deibert et al., } \\
1998 \text { [12] see } \\
\text { also Blitzer et al., } \\
1984 \text { [10] }\end{array}$ & $\begin{array}{l}\text { Case-control } \\
\text { with exposure } \\
\text { estimation }\end{array}$ & Age \\
\hline $\begin{array}{l}\text { Deibert et al., } \\
1998 \text { [12] see also } \\
\text { Blitzer et al., } \\
1984 \text { [10] }\end{array}$ & $\begin{array}{l}\text { Case-control } \\
\text { with exposure } \\
\text { estimation }\end{array}$ & $\begin{array}{l}\text { Binding } \\
\text { testing }\end{array}$ \\
\hline $\begin{array}{l}\text { Ekeland et al., } \\
1993[22]\end{array}$ & Case-control & Age \\
\hline
\end{tabular}

1993 [22]

Ekeland et al.,
1993 [22]
Case-control

Ability

\section{Results}

All injuries*

11-16:

1.0 (reference category)

$<11$ :

1.45 (95\% CI: $1.32-1.61)$

*1981-82 to $1993-94$

'... the percentage of the recommended release value for skiers who sustained a spiral fracture of the tibia averaged 158, whereas that for uninjured skiers averaged $111(\mathrm{p}<0.001)^{\prime}$

Lower extremity equipment-related (LEER) injuries

10-14: $\quad 1.0$ (reference category)

<10: $\quad 2.63$ (95\% CI: $1.01-6.83)^{*}$

*Authors report 'injury ratios' - the exposure proportion in the injured divided by the uninjured group. This measure depends on the prevalence of the risk factor category. However, a more epidemiologically appropriate and interpretable parameter is the odds ratio, which is presented here; regarding LEER injuries, this is a category defined a priori by the authors but this association should be established epidemiologically to truly know that a relation exists between equipment and these injuries; calculations from the authors' data

All injuries

Beginner:

16.4 (95\% CI: 4.6-59.3)*

$>$ Beginner:

1.0 (reference category)

*Authors report 'injury ratios' - the exposure proportion in the injured divided by the uninjured group. This measure depends on the prevalence of the risk factor category. However, a more epidemiologically appropriate and interpretable parameter is the odds ratio, which is presented here; calculations from the authors' data 


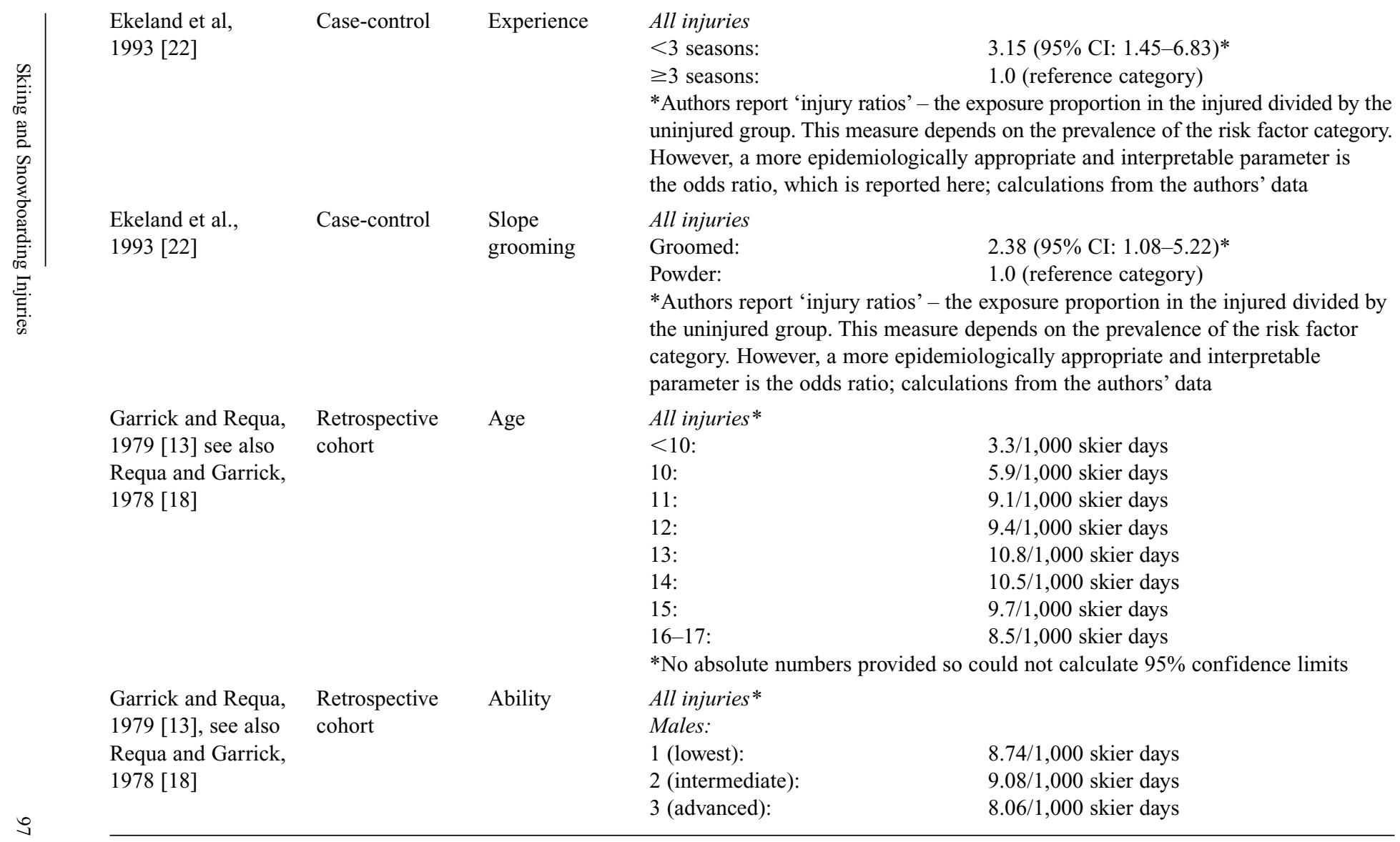


Table 3 (continued)

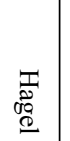

Garrick and Requa, Retrospective

1979 [13], see also cohort

Requa and Garrick,

1978 [18]

Giddings et al., 1993 [14]

Retrospective

cohort

Determinant

Results

All injuries

Females:

1 (lowest): $\quad 11.58 / 1,000$ skier days

2 (intermediate): $\quad 11.17 / 1,000$ skier days

3 (advanced): $\quad 9.07 / 1,000$ skier days

$*$ No absolute numbers provided so could not calculate $95 \%$ confidence limits

All injuries*

1 (lowest ability)

Males:

$8.74 / 1,000$ skier days

Females:

$11.58 / 1,000$ skier days

2 (intermediate ability)

Males:

9.08/1,000 skier days

Females:

$11.17 / 1,000$ skier days

3 (advanced ability)

Males: $\quad 8.06 / 1,000$ skier days

Females: $\quad 9.07 / 1,000$ skier days

*No absolute numbers provided so could not calculate $95 \%$ confidence limits

Head and face*

Under 13: $\quad 0.47 / 1,000$ skier days

$13+$ : $\quad 0.30 / 1,000$ skier days

Lower body*

Under 13:

$13+$ :

Lower leg fractures*

Under 13:

$13+$ :

$2.14 / 1,000$ skier days

$1.80 / 1,000$ skier days so could not calculate $95 \%$ confidence limits 


\begin{tabular}{|c|c|c|c|c|}
\hline $\begin{array}{l}\text { Goulet et al., } \\
1999 \text { [23] }\end{array}$ & Case-control & Age & \multicolumn{2}{|c|}{ All injuries } \\
\hline Goulet et al., & Case-control & Ability & \multicolumn{2}{|c|}{ All injuries } \\
\hline 1999 [23] & & & Low skill level: & $7.54 *(95 \%$ CI: $2.57-22.15)$ \\
\hline & & & High skill level: & 1.0 (reference category) \\
\hline & & & \multicolumn{2}{|c|}{$\begin{array}{l}\text { *Adjusted for equipment ownership and whether binding adjustment } \\
\text { was correct }\end{array}$} \\
\hline Goulet et al., & Case-control & Binding & \multicolumn{2}{|l|}{ All injuries } \\
\hline $1999[23]$ & & adjustment & Incorrect: & $2.11 *(95 \%$ CI: $1.02-4.33)$ \\
\hline & & & Correct: & 1.0 (reference category) \\
\hline & & & \multicolumn{2}{|c|}{ *Adjusted for equipment ownership and skill level } \\
\hline Goulet et al., & Case-control & Equipment & All injuries & \\
\hline 1999 [23] & & ownership & Rented: & 7.14* (95\% CI: 2.59-19.87) \\
\hline & & & Owned: & 1.0 (reference category) \\
\hline & & & \multicolumn{2}{|c|}{ *Adjusted for skill level and whether binding adjustment was correct } \\
\hline Goulet et al., & Case-control & Lessons & \multirow{2}{*}{\multicolumn{2}{|c|}{$\begin{array}{l}\text { All injuries } \\
\text { There was no evidence that formal training reduced the risk of injury after } \\
\text { adjusting for skill level, equipment ownership, and whether bindings were } \\
\text { adjusted correctly }\end{array}$}} \\
\hline 1999 [23] & & & & \\
\hline Requa and Garrick, & Retrospective & Ability & \multicolumn{2}{|c|}{ Males* } \\
\hline 1978 [18] see also & cohort & & Snowplow: & $6.3 / 1,000$ skier days \\
\hline Garrick and Requa, & & & Stem turn: & $10.3 / 1,000$ skier days \\
\hline 1979 [13] & & & Stem Christie: & $9.4 / 1,000$ skier days \\
\hline & & & Beginning parallel: & $8.9 / 1,000$ skier days \\
\hline & & & Parallel: & $8.6 / 1,000$ skier days \\
\hline & & & Short swing: & $6.9 / 1,000$ skier days \\
\hline
\end{tabular}


Table 3 (continued)

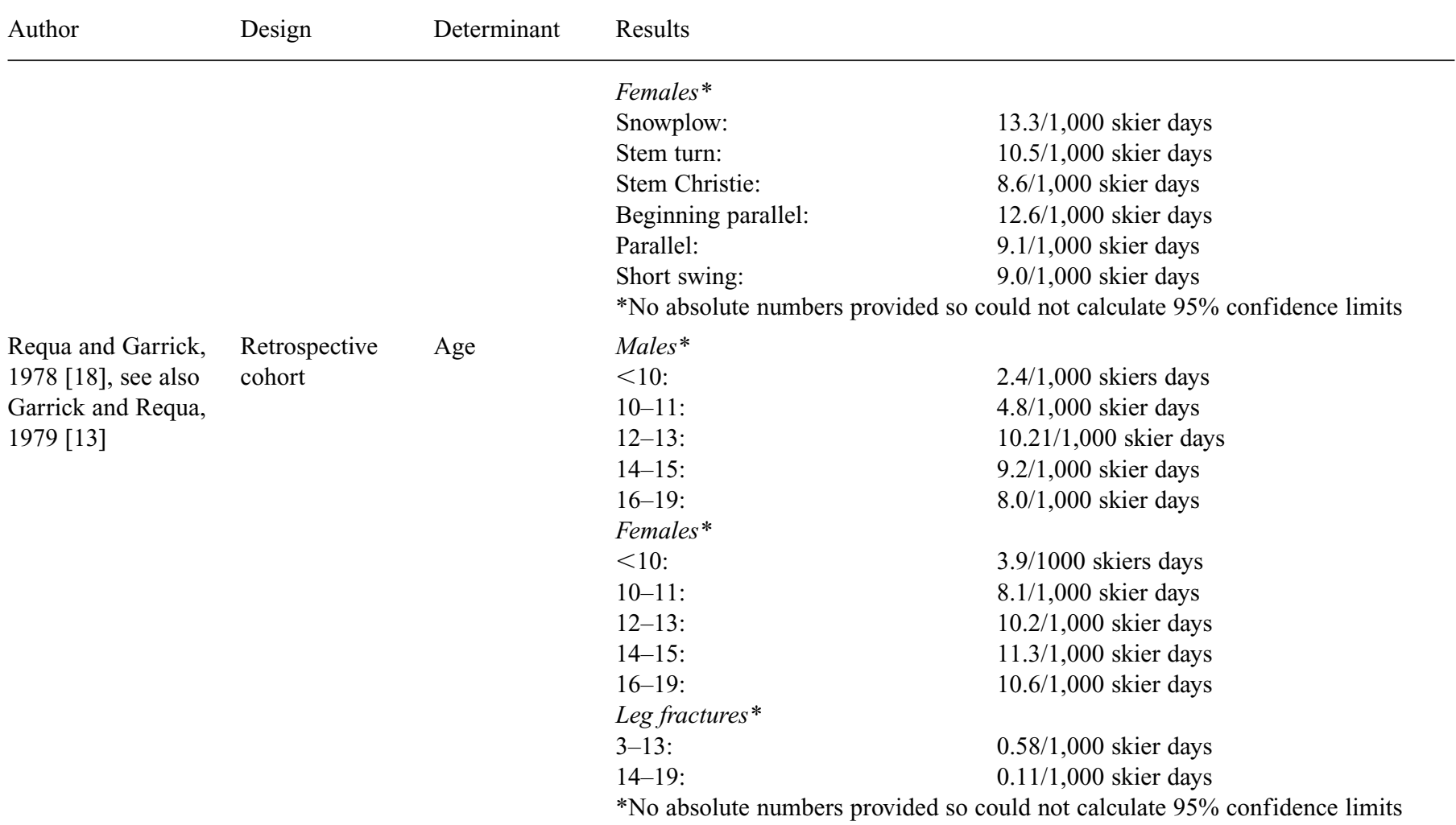




\begin{tabular}{|c|c|c|c|c|}
\hline $\begin{array}{l}\text { Requa and Garrick, } \\
1978 \text { [18] see also } \\
\text { Garrick and Requa, } \\
1979[13]\end{array}$ & $\begin{array}{l}\text { Retrospective } \\
\text { cohort }\end{array}$ & $\begin{array}{l}\text { Run } \\
\text { difficulty }\end{array}$ & $\begin{array}{l}\text { Easiest:* } \\
\text { More difficult:* } \\
\text { Most difficult:* } \\
\text { *No absolute number }\end{array}$ & $\begin{array}{l}10.9 / 1,000 \text { skier days } \\
9.2 / 1,000 \text { skier days } \\
8.8 / 1,000 \text { skier days } \\
\text { buld not calculate } 95 \% \text { confidence limits }\end{array}$ \\
\hline $\begin{array}{l}\text { Requa and Garrick, } \\
1978 \text { [18] see also } \\
\text { Garrick and Requa, } \\
1979 \text { [13] }\end{array}$ & $\begin{array}{l}\text { Retrospective } \\
\text { cohort }\end{array}$ & Sex & $\begin{array}{l}<10: * \\
\text { Males: } \\
\text { Females: } \\
\text { 10-11:* } \\
\text { Males: } \\
\text { Females: } \\
\text { 12-13:* } \\
\text { Males: } \\
\text { Females: } \\
\text { 14-15:* } \\
\text { Males: } \\
\text { Females: } \\
\text { 16-19:* } \\
\text { Males: } \\
\text { Females: } \\
\text { Snowplow ability:* } \\
\text { Males: } \\
\text { Females: } \\
\text { Stem turn:* } \\
\text { Males: } \\
\text { Females: } \\
\text { Stem Christie:* } \\
\text { Males: } \\
\text { Females: } \\
\text { Beginning parallel:* } \\
\text { Males: } \\
\text { Females: }\end{array}$ & $\begin{array}{l}2.4 / 1,000 \text { skier days } \\
3.9 / 1,000 \text { skier days } \\
\\
4.8 / 1,000 \text { skier days } \\
8.1 / 1,000 \text { skier days } \\
\\
10.2 / 1,000 \text { skier days } \\
10.2 / 1,000 \text { skier days } \\
9.2 / 1,000 \text { skier days } \\
11.3 / 1,000 \text { skier days } \\
8.0 / 1,000 \text { skier days } \\
10.6 / 1,000 \text { skier days } \\
\\
6.3 / 1,000 \text { skier days } \\
13.3 / 1,000 \text { skier days } \\
10.3 / 1,000 \text { skier days } \\
10.5 / 1,000 \text { skier days } \\
\\
9.4 / 1,000 \text { skier days } \\
8.6 / 1,000 \text { skier days } \\
8.9 / 1,000 \text { skier days } \\
12.6 / 1,000 \text { skier days }\end{array}$ \\
\hline
\end{tabular}


Table 3 (continued)

\begin{tabular}{l} 
Author Design \\
\hline
\end{tabular}

Ungerholm an

Case-control

Ability

Gustavsson,

1985 [33]

Ungerholm and
Gustavsson,
1985 [33]
Ungerholm and
Gustavsson,
1985 [33]

Case-control

Age

$1985[33$

$\begin{array}{ll}\text { Case-control } & \begin{array}{l}\text { Binding } \\ \text { adjustment }\end{array}\end{array}$

Parallel:*

$\begin{array}{ll}\text { Males: } & 8.6 / 1,000 \text { skier days } \\ \text { Females: } & 9.1 / 1,000 \text { skier days }\end{array}$

Short swing:*

Males:

$6.9 / 1,000$ skier days

Females:

$9.0 / 1,000$ skier days

*No absolute numbers provided so could not calculate $95 \%$ confidence limits

Lower extremity injury

Beginner: $\quad 3.7 *(95 \%$ CI: $1.66-8.21)$

Intermediate-expert: $\quad 1.0$ (reference category)

*Calculations from the authors data; odds ratio will be unbiased except for rounding errors but confidence limits will be too narrow depending on the extent of missing values (i.e., number of subjects used for precision estimate is based on total study numbers)

Lower extremity injury

In a case-control study of children $<17$ years, the authors noted that the average age was slightly younger in controls $(9.4)$ compared with cases $(10.7$ $\mathrm{p}<0.05)$

Lower extremity injury

Frequency of testing:

Never tested:

$0.70 *$ (95\% CI: $0.32-1.54)$

Tested:

1.0 (reference category)

The authors noted significantly more deviation from recommended values in the toe release setting of the binding in the injured compared with the uninjured group $(\mathrm{p}<0.01)$

The authors noted significantly more deviation between the recommended toe release setting and the actual force required to release the binding in the injured compared with the uninjured group $(\mathrm{p}<0.01)$ 
Ungerholm and

Gustavsson,

1985 [33]

Ungerholm and

Gustavsson,

1985 [33]

Ungerholm and

Gustavsson,

1985 [33]
*Calculations from the authors' data; odds ratio will be unbiased except for rounding errors but confidence limits will be too narrow depending on the extent of missing values (i.e., number of subjects used for precision estimate is based on total study numbers)

Lower extremity injury

Rent-Borrow: $\quad 0.61 *(95 \%$ CI: $0.26-1.39)$

Own:

1.0 (reference category)

*Calculations from the authors' data; odds ratio will be unbiased except for rounding errors but confidence limits will be too narrow depending on the extent of missing values (i.e., number of subjects used for precision estimate is based on total study numbers)

Experience

Lower extremity injury

1 week or less:

$4.82 *(95 \%$ CI: $1.77-13.09)$

$>1$ week: $\quad 1.0$ (reference category)

*Calculations from the authors' data; odds ratio will be unbiased except for rounding errors but confidence limits will be too narrow depending on the extent of missing values (i.e., number of subjects used for precision estimate is based on total study numbers)

Lower extremity injury

Males:

$$
0.81 * \text { (95\% CI: } 0.37-1.78)
$$

Females:

1.0 (reference category)

*Calculations from the authors' data; odds ratio will be unbiased except for rounding errors but confidence limits will be too narrow depending on the extent of missing values (i.e., number of subjects used for precision estimate is based on total study numbers) 
Table 3 (continued)

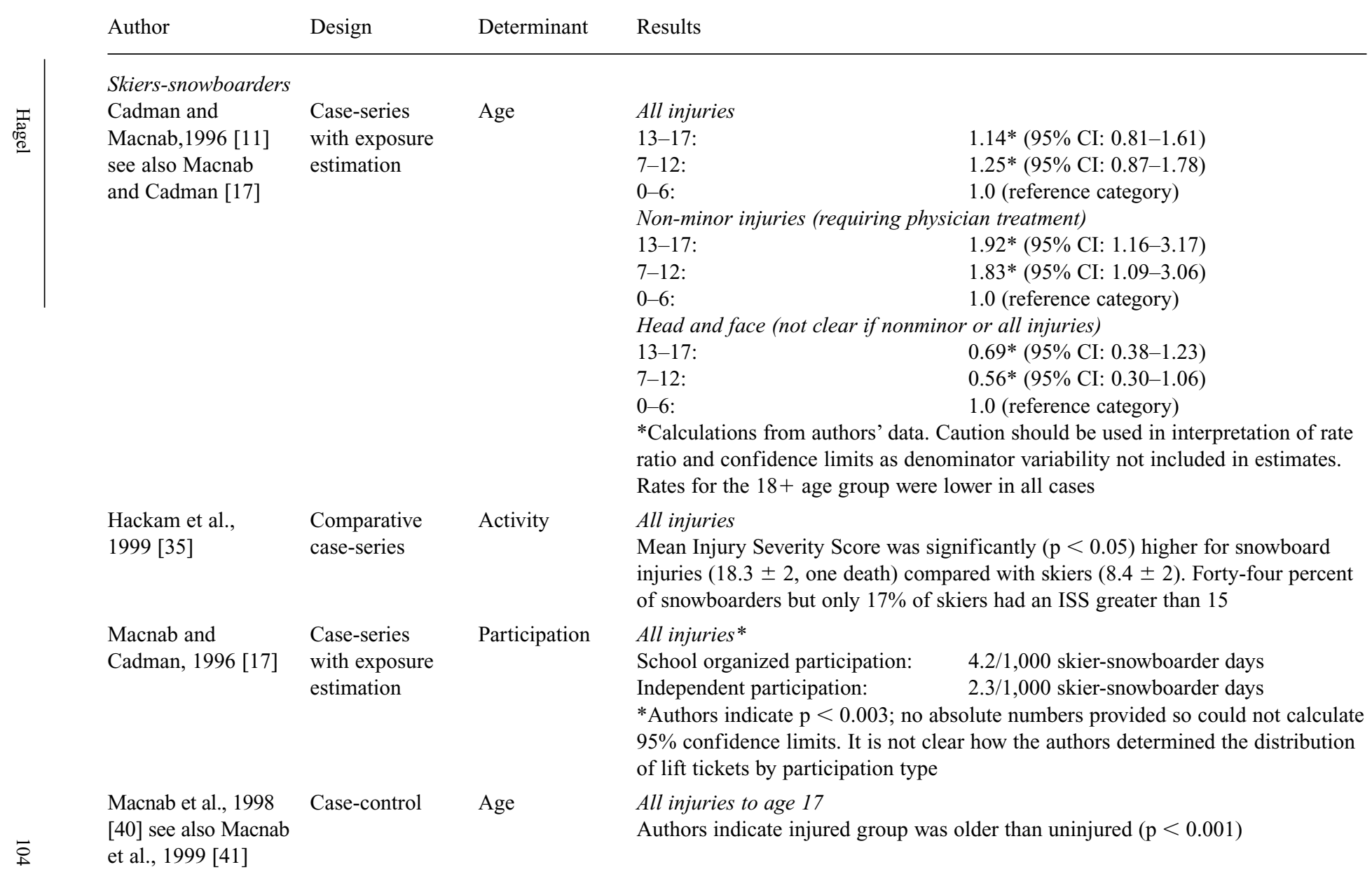




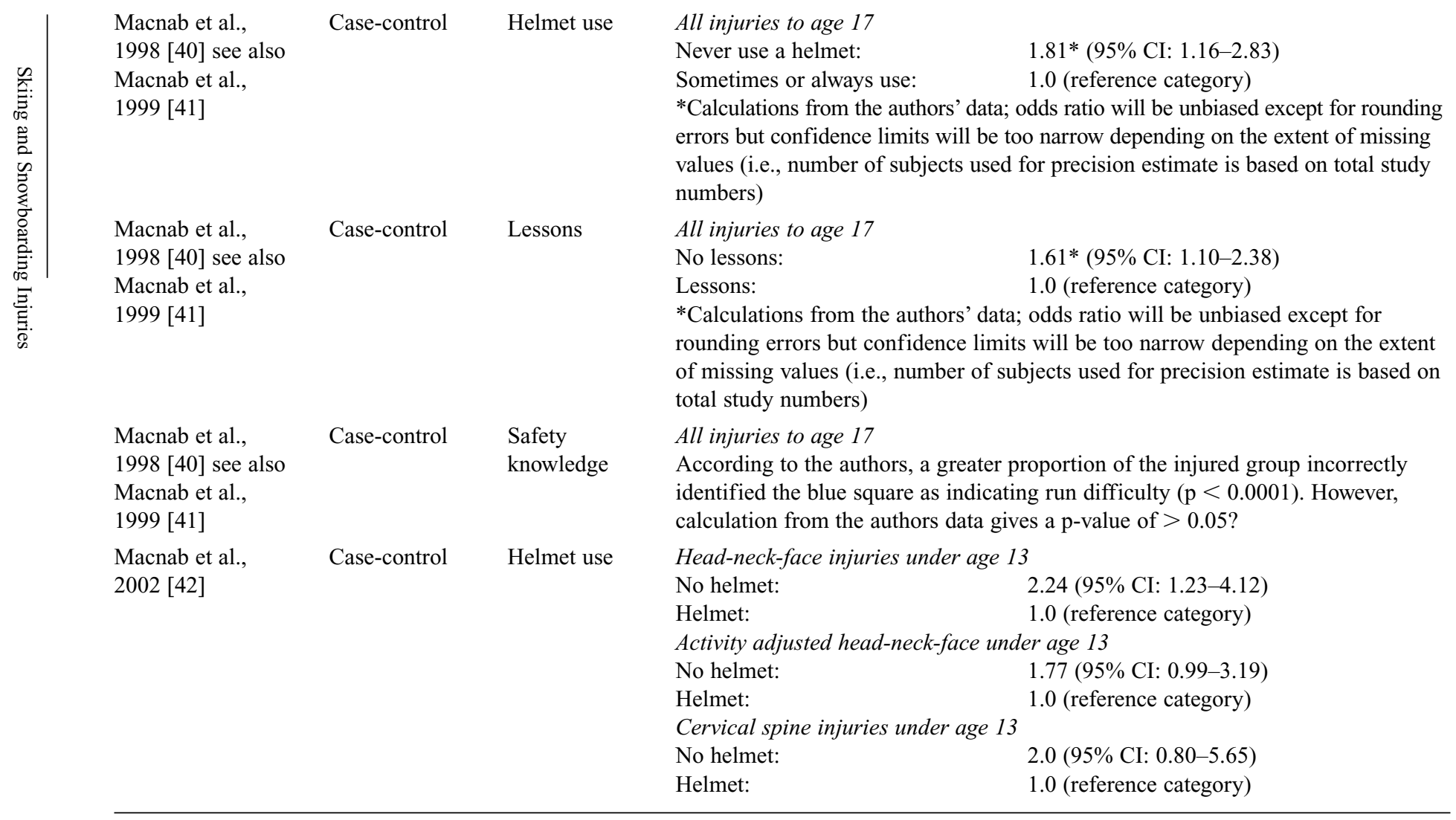


Table 3 (continued)

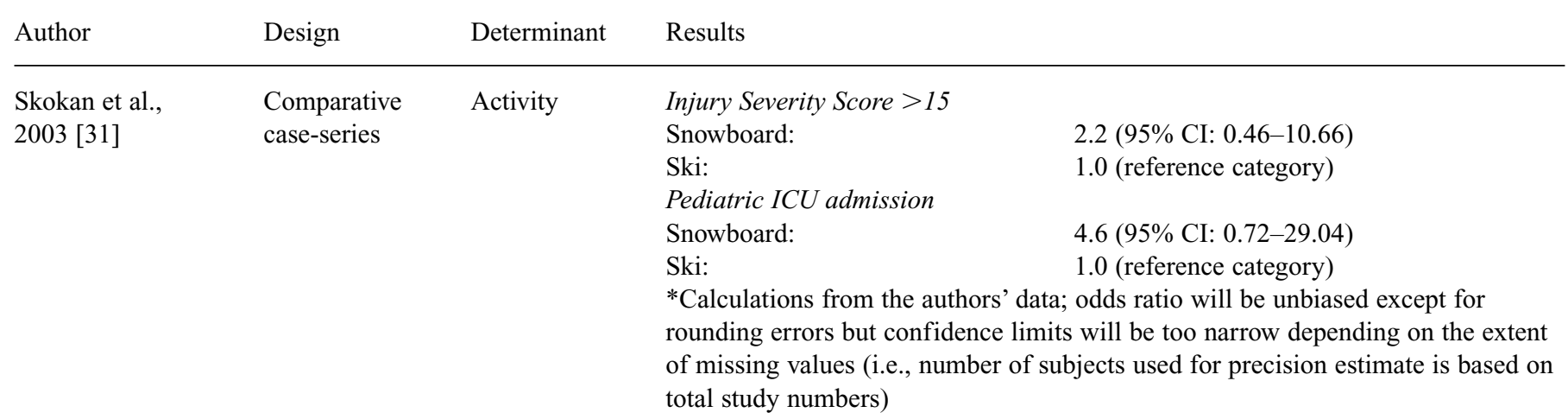

Snowboarders

Machold et al., 2000 [16]

\section{Retrospective} cohort

Machold et al., 2000 [16]

Retrospective cohort
Retrospective cohort
Experience

Helmet use ঞ
Machold et al., 2000 [16]

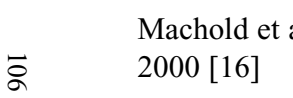

colort

A

\section{All injuries*}

Each additional half-day: $\quad 0.91(95 \%$ CI: $0.82-1.0)$

Half-days experience:

1.0 (reference category)

Moderate-severe wrist injuries*

Each additional half-day: $\quad 0.78$ (95\% CI: 0.61-0.99)

Half-days experience:

$0.78(95 \%$ CI: $0.61-0.99)$
1.0 (reference category)

*Adjusted for age, sex, use of wrist protection, number of prior sports injuries, type of shoes, and snow condition

\section{Head injuries*}

Helmet:

No helmet:

0 injuries in 196 snowboarders

*Calculations from authors' data

Severe wrist injuries

Falls training:

No falls training:

*Calculations from authors' data
17 injuries in 2,366 snowboarders

$1.50 *$ (95\% CI: 0.76-2.97)

1.0 (reference category) 


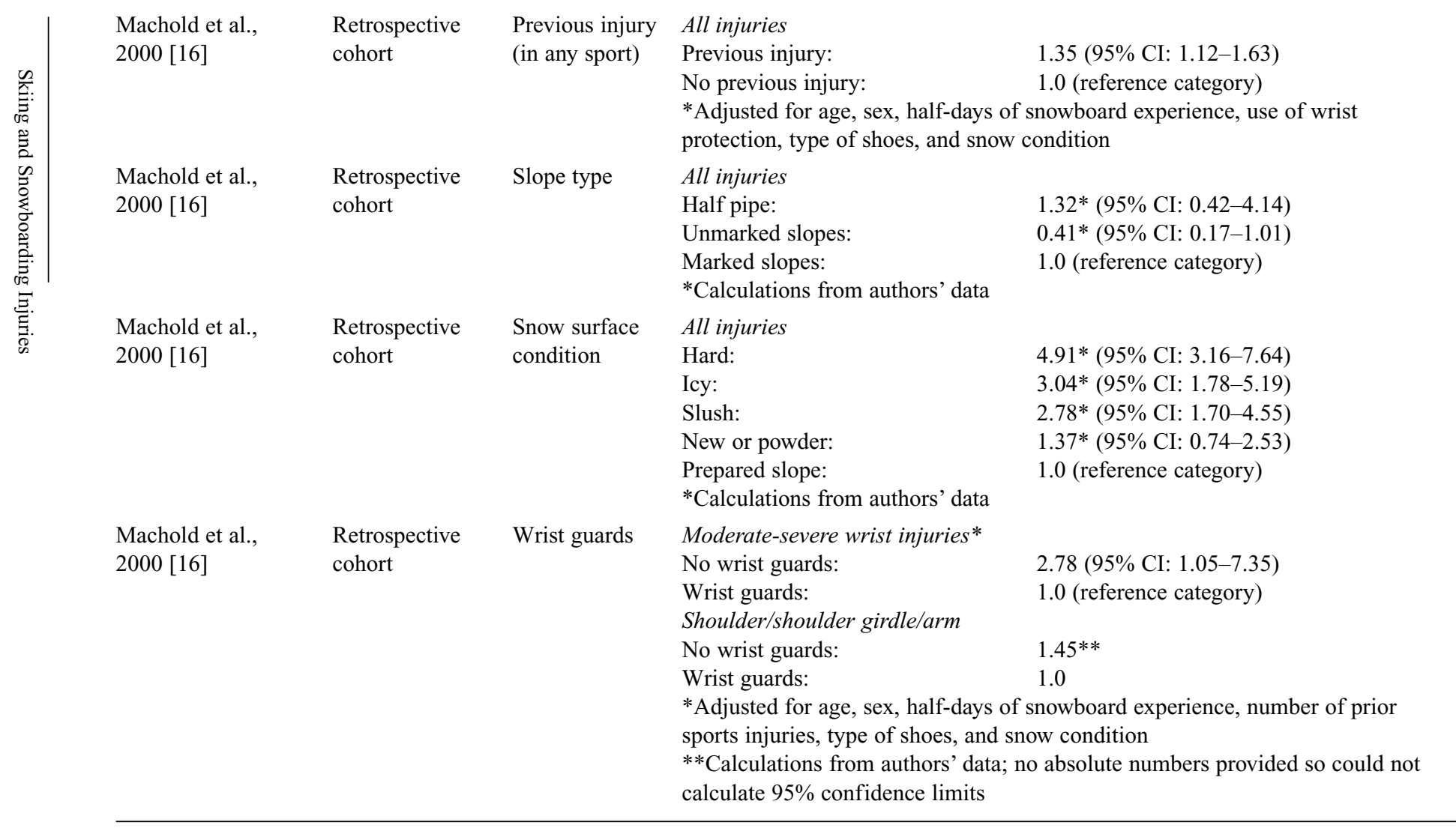


If absolute numbers of injuries were available from the study, confidence limits (the range defining the confidence interval; $\mathrm{CI}$ ) could be calculated indicating the precision of the relative measure of association. The interpretation of a $95 \% \mathrm{CI}$ is that if the study were repeated 100 times, 95 of the CIs calculated would capture the true relative measure of association (e.g., odds ratio), assuming the absence of bias. The more narrow the interval, the greater the precision of the estimate. If the confidence limits exclude the null value of 1.0, the risk is significantly different at $\mathrm{p}<0.05$.

The following sections detail the intrinsic and extrinsic determinants of injury in skiers and snowboarders.

\section{Intrinsic Risk Factors}

The inherent characteristics of an individual that influence injury risk in skiers and snowboarders include ability and experience, age, past injury and sex. The literature on the effect of lessons is equivocal.

\section{Ability and Experience}

Perhaps the most ubiquitous finding in the ski injury literature is that those with lower ability or less experience are at greater risk of injury. This is certainly the case for studies conducted on child and adolescent skiers [10, 22, 23, 33] and snowboarders [16], although the association is less clear in some investigations $[13,18]$.

\section{Age}

Generally, younger age groups have been shown to have a greater injury risk in skiing [12, 43-53], and snowboarding [46, 52, 54]. Adolescent skiers are commonly found to have higher injury rates than the youngest age groups [10, $11,18,40,41]$, although the opposite is true for lower extremity injuries, particularly fractures $[10,14,22,33]$.

For all injuries combined in skiers, Blitzer et al. [10] noted a higher injury rate in 11-13-year-olds compared with those under 11 and those 14-16. The rate of tibial fractures in 14-16-year-olds was less than half the rate in those $11-13(\mathrm{p}<0.05)$. Similarly, the rate of thumb injuries in those $11-13$ was almost 4 times the rate in children 10 and under.

The 1981-82 to 1993-94 data from Deibert et al. [12] indicate that, for all injuries combined, those under 11 have a 45\% (95\% CI: 32-61\%) increased risk compared with those 11-16.

Based on the case-control study by Ekeland et al. [22] the risk of a lower extremity equipment-related injury in those under age 10 was $2.63(95 \%$ 
CI: $1.01-6.83)$ times the risk in those aged 10-14. It should be noted that the lower extremity equipment-related category of injuries is defined a priori by the authors when this relation should have been established epidemiologically to truly know that the injury is 'equipment related'.

No absolute numbers were available from the retrospective cohort study conducted by Garrick and Requa [13], so no CIs could be calculated. However, their data indicate that those under age 10 had the lowest injury rates. The injury rate climbed monotonically to a peak of 10.8 injuries per 1,000 skier days at age 13 , and then steadily decreased through age 17 . This pattern was similar for males and females although the peak injury rate for females was $11.3 / 1,000$ skier days in the 14-15 age group [18].

Giddings et al. [14] conducted a case-series investigation of skiers comparing injured children under age 13 to those 13 and older. Unfortunately, the authors included adolescents with adults, groups that likely have markedly different injury rates. Children under 13 had significantly higher rates of head and face and lower body injuries compared with the $13+$ age group. In addition, the lower leg fracture rate in those under 13 was over six times the rate in those 13 and older.

In their case-control study of children under 13, Goulet et al. [23] noted no difference between injured and uninjured skiers in terms of the age distribution.

With the outcome of lower extremity injuries, Ungerholm et al. [33] in their case-control study of injured skiers under 17, found that the average age was slightly younger in controls (9.4) compared with cases $(10.7 ; \mathrm{p}<0.05)$.

For skiers and snowboarders combined, data from Cadman and Macnab [11] show that the rate of nonminor injuries is significantly higher in children aged 7-17 compared with those 6 and under. The authors noted this association again in subsequent studies [40,41]. However, the rate of head and face injuries in those 6 years of age and under may be higher than those $7-17$ years of age.

A methodological issue to keep in mind when interpreting the age-related risk of injury is that younger age groups may report their injuries more than older age groups [55-57]. The effect of this 'over-reporting', however, would likely diminish as injury severity increased.

Despite the potential for any over-reporting, it is likely that the age differences in injury risk at least in part relate to experience and equipment. As was already stated, some authors even suggest that skiing may be too difficult a sport for children owing to the complexity of the task and the capability of reaching high speeds quickly [7]. It has also been suggested that 'In general, children use inferior equipment, which is often old and poorly serviced, and frequently their bindings are not set appropriately for their weight' [19]. These issues will be revisited in subsequent, relevant sections. 


\section{Lessons Including Safety Knowledge}

Although it seems logical that lessons would decrease the risk of injury in skiing and snowboarding, the empirical evidence is equivocal. After adjusting for skill level, proper binding adjustment and equipment ownership, Goulet et al. [23] noted no relation between formal training and injury risk. The authors suggest that this finding may be due to methodological limitations. However, they also suggest that by far the more important factor may be skill level and that 'formal ski lessons ... be viewed as one among several tools... to raise the level of skill of the young skier' [23]. Another possibility is that young skiers taking lessons may be more likely to report their injuries as they are being supervised by an instructor, as has been found in other investigations [56], which would bias the association toward finding no effect, assuming lessons are protective.

Similarly in snowboarders, Machold et al. [16] noted that falls training may actually increase the risk of a severe wrist injury. It was not clear from that investigation whether those who took the falls training were of lower ability to begin with (i.e., the results may be confounded by ability). It may also be that again, like in the study by Goulet et al. [23] those taking lessons were more likely to report injuries due to their supervision.

Conversely, the data of Macnab et al. [40] indicate that not having taken lessons is a risk factor for injury. These investigators also suggest that the injured group was less likely to identify the blue square as indicating run difficulty compared with an uninjured series. However, low response rates and other methodological limitations make the results of this investigation less compelling than the work of Machold et al. [16] or Goulet et al. [23].

These conflicting results indicate the need for further research into the nature and extent of ski and snowboard lessons.

\section{Past Injury}

Only one study of snowboarding injuries in students has examined the effect of past injury on subsequent injury risk. In their retrospective cohort study of Austrian school aged snowboarders, Machold et al. [16] found that those with a past sport injury were 1.35 times more likely to sustain a subsequent snowboarding injury compared with those reporting no prior sport injury $(95 \%$ CI: 1.12-1.63). The authors suggest this result is due to greater risk-taking by some individuals, but this would indicate that the participation characteristics of those with and without a prior sports injury were different. This seems unlikely as the authors accounted for age, sex, experience, and other factors in the analysis, factors that would 'equalize' the groups for risk-taking propensity. An arguably more tenable explanation may be that those with a prior sports injury have not received adequate care for the injury or have not allowed sufficient time for healing and rehabilitation. 
$\operatorname{Sex}$

Although males generally garner the label of risk-takers, the child and adolescent ski injury literature does not bear this out. In their retrospective cohort study of alpine junior ski racers at a world junior competition, Bergstrøm et al. [9] noted 4 injuries in girls for a rate of 8.9 injuries per 1,000 runs. There were no injuries for boys in 546 runs. Garrick and Requa [13, 18] in their retrospective cohort study of child and adolescent skiers noted higher rates in girls in almost every age group and ability level. These differences were most pronounced in the under 12 and lowest ability level categories. Finally, focusing on lower extremity injuries in skiers, Ungerholm and Gustavsson [33] in their case-control study found a lower rate in males (OR: $0.81 ; 95 \% \mathrm{CI}$ : 0.37-1.78). The effect, however, was not statistically significant.

It is not known whether these results reflect an actual increase in injury rates for females or merely a greater likelihood of reporting [16, 55-57]. Similarly, when particular injuries or body regions are the focus, substantial differences between males and females may emerge with females at greater risk of a lower extremity injury [58].

\section{Extrinsic Risk Factors}

A number of factors external to the individual (i.e., extrinsic factors) have been shown to influence the risk of injury in skiers and snowboarders. These include binding adjustment, helmet use, slope characteristics, and wrist-guard use in snowboarders. Those investigations examining the effect of activity and equipment ownership on injury risk are less consistent.

\section{Activity}

There is some evidence to suggest that the severity of injury may be greater in young snowboarders compared with young skiers [31, 35]. However, others suggest greater injury severity in young skiers [29, 30].

Hackam et al. [35] conducted a case-series investigation of children under age 17 admitted to hospital for skiing and snowboarding injuries. Although no denominator data were available to examine the rate of injuries in the two activities, the authors noted that the mean ISS was significantly $(\mathrm{p}<0.05)$ higher for snowboard injuries $(18.3 \pm 2$, one death) compared with skiers $(8.4 \pm 2)$. Fortyfour percent of snowboarders but only $17 \%$ of skiers had an ISS greater than 15 .

The data from the case-series investigation by Skokan et al. [31] also allow comparisons of the risk of severe injury in snowboarding compared with skiing in children under 18 requiring hospitalization for winter sports injuries. Although not statistically significant at $p<0.05$, the data suggest that snowboarders are 
2.2 times more likely to have an ISS $>15$ (95\% CI: $0.46-10.66)$. Similarly, snowboarders were estimated to have an almost 5-fold (95\% CI: $0.72-29.04)$ increase in the likelihood of being admitted to the pediatric ICU.

Interestingly, comparing the findings of two consecutive studies on skiers and snowboarders admitted to hospital for their injuries, Shorter et al. [29, 30] suggest a lower injury severity in snowboarders. The authors base this conclusion on the Pediatric Trauma Score, shorter hospital stay and lower average cost of injury. However, these studies were conducted over different time periods, which may account for the differences in the findings.

The strongest evidence suggests greater injury severity in snowboarders compared with skiers. Possible explanations for the difference may relate to the focus on aerial maneuvers characteristic of snowboarding. In addition, the very young, beginner snowboarders of the mid 1990s may now be the more experienced, perhaps more daring adolescents of today.

\section{Binding Adjustment and Equipment Ownership}

One study published in 1984 found that less than $25 \%$ of uninjured children's $(<15)$ bindings had correct (under $20 \%$ deviation from recommended) toe release settings [59]. In addition, $40 \%$ of the series had never adjusted their bindings. Sadly, the situation has changed little. Goulet et al. [23] noted that $56 \%$ of injured and $46 \%$ of uninjured subjects in their 1999 case-control study of child injury risk factors had incorrect binding adjustment settings using a criterion of $20 \%$ deviation from recommended values.

There is evidence to suggest that those children and adolescents who own their own equipment have a lower risk of injury [10, 23]. In their case-control study, Goulet et al. [23] noted that those children under 13 years who rented their equipment had a 7 -fold (95\% CI: 2.59-19.87) increased risk of injury compared with children who owned their equipment, after controlling for skill level and proper binding adjustment. Ungerholm and Gustavsson [33] did not find any relation between equipment ownership and lower extremity injury risk, although the design and analysis of this study was weaker than that of Goulet et al. [23].

Similarly, those children with properly adjusted bindings are significantly less likely to sustain injuries, particularly of the lower leg [12,33]. For all injuries combined, Goulet et al. [23] found a 2 -fold (95\% CI: 1.02-4.33) greater risk of injury in children under 13 when the binding settings deviated more than $20 \%$ from recommended values, after adjustment for skill level and equipment ownership.

\section{Helmet Use}

Surprisingly little research has been conducted on the effectiveness of helmets in preventing head injuries in skiers and snowboarders. Oh and Schmid [60] 
suggested mandatory helmet use for children and adolescents up to 17 years old as long ago as 1983. However, few studies since that time provide data on the issue in children and adolescents [16, 40, 42].

In their first investigation of the helmet issue, Macnab et al. [42] noted that injured subjects were $81 \%$ (95\% CI: 16-283\%) more likely to have never used a helmet. In their subsequent case-control study, the authors found that failure to use a helmet increased the risk of a head injury by 1.8 -fold (95\% CI: $0.99-3.19)$. They also reported no associated increase in the risk of a cervical spine injury with helmet use. Similarly, Machold et al. [16] found no head injuries in the cohort of 196 snowboarders using a helmet, but 17 in the 2,366 not using one. The small number of injured individuals and subsequent lack of control for possible confounding factors make the results of these studies encouraging, but far from conclusive.

There are also arguments that helmets may increase the risk-taking behavior of the user [61] or that helmets may alter the ability to hear, see, or balance, leading to skier error and subsequently more frequent or severe injury $[29,41]$. Instances of death $[62,63]$ and head and face injury [41, 64] among snowboarders and skiers wearing helmets indicate the need for additional research.

\section{Slope Characteristics}

The data on slope characteristics suggest a greater risk of skiing injury on groomed runs compared with powder [22] and easy compared with more difficult runs [18]. For snowboarders, the injury risk may be greater on the half-pipe compared with marked runs, and on hard, icy or slushy terrain compared with prepared slopes [16].

\section{Wrist-Guards}

The retrospective cohort study by Machold et al. [16] is the only investigation to examine wrist-guard effectiveness in children and adolescents. These investigators found that those not using wrist-guards were 2.78 (95\% CI: 1.05-7.35) times more likely to sustain a moderate-severe wrist injury compared with those using wrist-guards. Further, and importantly, there was no evidence to suggest that using wrist-guards increased the risk of a shoulder, shoulder girdle, or arm injury. These results mirror the findings of other investigations in all age groups [65-68].

\section{Suggestions for Injury Prevention}

Much of the research reviewed was descriptive in nature. Only a few studies represent rigorous investigations of specific risk factors and outcomes. 
Therefore, the suggestions for prevention must be viewed in light of these caveats.

(1) From compelling evidence in bicycling $[69,70]$, and the encouraging results from the ski and snowboard injury literature, children and adolescents should be encouraged to wear helmets.

(2) Use of wrist guards will likely reduce the frequency and severity of one of the most common injuries seen in snowboarders.

(3) Children and adolescents should not participate on runs that exceed their ability. They should stay in control and not speed down the hill. Parental supervision or a greater presence of ski patrol members at ski areas would likely reduce the number of children and adolescents traveling at dangerous speeds or who are out of control. If at all possible, skiers and snowboarders should avoid participation on hard, icy or slushy terrain. Ski areas need to ensure runs are adequately groomed.

(4) Equipment for children should fit properly and be regularly maintained, including frequent binding adjustment. This is particularly true for the youngest age groups and females, individuals who may be most susceptible to lower extremity injuries.

(5) Lessons should be taken with the goal of increasing ability and experience as well as increasing knowledge of hill etiquette. However, children and adolescents should be reminded that taking lessons does not guarantee protection from injury and that they must still assume responsibility for their actions.

\section{Suggestions for Future Research}

As I have alluded to, the skiing and snowboarding injury literature lacks high quality investigations focusing on specific questions (e.g., the effect of helmet use on head injury risk) and adhering to rigorous epidemiological principles. Case-series studies abound, but reveal little about risk and protective factors. A control group identifying the prevalence of the risk or protective factor in the source population that produced the injured cases is required to identify these relationships [71]. Case-control studies are an optimal approach, given their efficiency relative to nonexperimental cohort studies and randomized controlled trials, and, if properly conducted [71-73], they can provide valid results. A variant of the case-control study, the case-crossover approach [74] focuses on transient determinants (i.e., those which can change over time) such as protective equipment use or slope type in relation to a specific injury. This design has enormous potential to elucidate many important relationships.

Based on the state of the literature, a number of recommendations for further research are outlined. 
(1) The effectiveness of helmets in skiers and snowboarders needs to be clarified. Specifically, the effect of helmet use on head and neck injury risk needs to be evaluated, along with whether helmet use changes behavior due to a false sense of security. Finally, the design of helmets should be studied to ensure they provide optimal protection without influencing the user's ability to see, hear or balance.

(2) Further work needs to be done on the influence of lessons on injury risk. Certainly, engaging in an activity without having any background knowledge is inherently dangerous. However, the content of instructional programs should be investigated further for skiers and snowboarders.

(3) Based on the trends identified from the excellent work of Deibert et al. [12], severe knee sprains continue to be a problem. Although some investigators suggest that current release binding systems are optimal and cannot prevent serious knee injuries $[12,75]$, the AFNOR, the French standardization organization, suggests that binding adjustment settings for women and lighter men be lowered in response to a rise in the rate of knee anterior cruciate ligament injury [76]. The benefits of this would likely be realized by younger age groups as well.

(4) An absence of a reduction in head injuries overall, and an increase in spinal injuries over a time period when most other types of injuries have decreased, evident in the skier injury trends identified by Deibert et al. [12] warrants serious concern. This is particularly true given similar trends for skiers, along with the substantial increase in neck injuries in snowboarders, found in the study by Hagel et al. [15]. Some authors speculate that the popularization of snow-parks (i.e., play areas), or dedicated areas with, for example, half-pipes, rails, and other slope modifications that accommodate jumping may be partly responsible for the trends [58]. The greater use of snow-parks by snowboarders in the past few years may also be partly responsible for the evidence suggesting greater injury severity in this group compared with skiers. Further study into the cause of these concerning trends and ways to reduce head and spine injuries in child and adolescent skiers and snowboarders is needed. This is particularly true for snowboarders given that this activity continues to enjoy a greater number of participants every year.

(5) The introduction of new equipment such as skiboards with nonrelease bindings [77] should be carefully monitored. There is evidence that these devices may increase the risk of lower leg injuries including tibial fractures $[46,78]$ due to the nonrelease binding, although knee injuries may be less likely [46].

(6) Revisiting methodological issues, when studies are conducted, they should be focused on defined injuries. There is evidence that the relationships 
between age, sex, and activity can change depending on which body region of injury is studied [58]. Some of the most successful case-control studies in terms of furthering our knowledge about injury etiology in sport and recreational activities restricted their analysis to injured individuals; cases being those with a particular body region of injury, while controls were those who sustained injuries to other body regions. This approach has been used in the study of risk factors for bicycling [69, 70, 79], in-line skating [80], and skiing injuries [81]. The key to the use of an injured control group is to ensure there is no relation between the control injuries (e.g., arm and leg injuries) and the determinant of interest (e.g., helmet use).

\section{References}

1 de Leös M: Epidemiology of sports injuries in the Swiss organization 'Youth and Sports' 1987-1989: Injuries, exposure and risks of main diagnoses. Int J Sports Med 1995;16:134-138.

2 Health Canada: For the Safety of Canadian Children and Youth. From Injury Data to Preventive Measures. Minister of Public Works and Government Services Canada Ottawa, Canada 1997.

3 Mohtadi N: Pediatric sport-related injuries: A short-term prospective study. Clin J Sport Med 1991;1:197-201.

4 Marchie AG, Di Bello D, Messi G, Gazzola G: Permanent sequelae in sports injuries: A population based study. Arch Dis Child 1999;81:324-328.

5 Sahlin Y: Sport accidents in children. Br J Sports Med 1990;24:40-44.

6 Ytterstad B: The Harstad injury prevention study: The epidemiology of sports injuries. An 8 year study. Br J Sports Med 1996;30:64-68.

7 Danielsson K: Swedish measures for reduction of skiing accidents with special reference to children. Orthop Clin North Am 1976;7:59-61.

8 Michaud PA, Renaud A, Narring F: Sports activities related to injuries? A survey among 9-19 year olds in Switzerland. Inj Prev 2001;7:41-45.

9 Bergstrøm KA, Bergstrøm A, Ekeland A: Organisation of safety measures in an Alpine World Junior Championship. Br J Sports Med 2001;35:321-324.

10 Blitzer C, Johnson R, Ettlinger C, Aggeborn K: Downhill skiing injuries in children. Am J Sports Med 1984;12:142-147.

11 Cadman R, Macnab AJ: Age and gender: Two epidemiological factors in skiing and snowboarding injury; in Mote CD Jr, Johnson RJ, Hauser W, Schaff PS (eds): Skiing Trauma and Safety vol 10, ASTM STP 1266. Philadelphia, American Society for Testing and Materials, 1996, pp 58-65.

12 Deibert M, Aronsson D, Johnson R, Ettlinger C, Shealy J: Skiing injuries in children, adolescents, and adults. J Bone Jt Surg 1998;80A:25-32.

13 Garrick J, Requa R: Injury patterns in children and adolescent skiers. Am J Sports Med 1979;7:245-248.

14 Giddings PH, McCallum IG, Duff PA: Children's skiing injuries in Victoria, Australia; in Johnson RJ, Mote CD Jr, Zelcer J (eds): Skiing Trauma and Safety: Ninth International Symposium, ASTM STP 1182. Philadelphia, American Society for Testing and Materials, 1993, pp 50-54.

15 Hagel BE, Pless IB, Platt RW: Trends in emergency department reported head and neck injuries among skiers and snowboarders. Can J Public Health 2003;94:458-462.

16 Machold W, Kwasny O, Gäßler P, et al: Risk of injury through snowboarding. J Trauma 2000;48:1109-1114.

17 Macnab AJ, Cadman RE, Gagnon F: Demographics of alpine skiing and snowboarding injury: Lessons for prevention programs. Inj Prev 1996;2:286-289.

18 Requa R, Garrick J: Skiing injuries in children and adolescents. International Series on Sport Sciences: Skiing Safety II 1978;5:5-10. 

193-195.

20 Wyatt J, Beattie T: Paediatric injuries on an artificial ski slope. Injury 1995;26:87-88.

21 Drkulec JA, Letts M: Snowboarding injuries in children. Can J Surg 2001;44:435-439.

Ekeland A, Nordsletten L, Lystad H, Holtmoen Å: Alpine skiing injuries in children; in Johnson RJ, Mote CD Jr, Zelcer J (eds): Skiing Trauma and Safety: Ninth International Symposium, ASTM STP 1182. Philadelphia, American Society for Testing and Materials, 1993, pp 43-49.

Goulet C, Régnier G, Grimard G, Valois P, Villeneuve P: Risk factors associated with alpine skiing injuries in children: A case-control study. Am J Sports Med 1999;27:644-650.

24 Hagel BE, Meeuwisse WH, Mohtadi NGH, Fick GH: Skiing and snowboarding injuries in the children and adolescents of southern Alberta. Clin J Sport Med 1999;9:9-17.

25 Heir S, Krosshaug T, Rodven A, Ekeland A: Injuries in alpine skiing related to age groups 'abstract'. Knee Sug, Sports Traumatol Arthrosc 2002;10:385-386.

26 Hill S: Incidence of tibial fracture in child skiers. Br J Sports Med 1989;23:169-170.

27 Molinari M, Bertoldi L, Zucco P: Epidemiological aspects of skiing injuries in children under 15. A four-year review. J Sports Traumatol Rel Res 1994;16:39-47.

28 Molinari M, Bertoldi L, Zucco P: Epidemiology of skiing injuries in a large Italian ski resort during 1988-1992; in Mote CD Jr, Johnson RJ, Hauser W, Schaff PS (eds): Skiing Trauma and Safety, vol 10, ASTM STP 1266. Philadelphia, American Society for Testing and Materials, 1996, pp 87-97.

29 Shorter N, Jensen P, Harmon B, Mooney D: Skiing injuries in children and adolescents. J Trauma 1996;40:997-1001.

30 Shorter NA, Mooney DP, Harmon BJ: Snowboarding injuries in children and adolescents. Am J Emerg Med 1999;17:261-263.

31 Skokan EG, Junkins JEP, Kadish H: Serious winter sport injuries in children and adolescents requiring hospitalization. Am J Emerg Med 2003;21:95-99.

32 Ungerholm S, Engkvist O, Gierup J, Lindsjö U, Balkfors B: Skiing injuries in children and adults: A comparative study from an 8-year period. Int J Sports Med 1983;4:236-240.

33 Ungerholm S, Gustavsson J: Skiing safety in children: A prospective study of downhill skiing injuries and their relation to the skier and his equipment. Int J Sports Med 1985;6:353-358.

34 Ungerholm S, Gierup J, Lindsjo U, Magnusson A: Skiing injuries in children: Lower leg fractures. Int J Sports Med 1985;6:292-297.

35 Hackam DJ, Kreller M, Pearl RH: Snow-related recreational injuries in children: Assessment of morbidity and management strategies. J Pediatr Surg 1999;34:65-68; discussion 69.

36 Joint Committee on Injury Scaling: The Abbreviated Injury Scale (AIS), 1980 Revision. Arlington Heights, IL, American Association for Automotive Medicine, 1980.

37 Baker SP, O’Neill B: The injury severity score: An update. J Trauma 1976;16:882-885.

38 Tepas JJ, Mollitt DL, Talbert JL, Bryant M: The pediatric trauma score as a predictor of injury severity in the injured child. J Pediatr Surg 1987;22:14-18.

39 Committee on Injury Scaling: The abbreviated injury scale: 1990 revision. Des Plaines, IL, Association for the Advancement of Automotive Medicine, 1990.

40 Macnab AJ, Cadman RE, Greenlaw JV: Safety knowledge and risk behavior of injured and uninjured young skiers and snowboarders. Paediatrics and Child Health 1998;3:321-324.

41 Macnab AJ, Cadman RE, Greenlaw JV: A comparison of knowledge and behavior in young injured and non-injured skiers; in Johnson RJ (ed): Skiing Trauma and Safety, vol 12, ASTM STP 1345. Conshohocken, PA, American Society for Testing and Materials, 1999, pp 3-10.

42 Macnab AJ, Smith T, Gagnon FA, Macnab M: Effect of helmet wear on the incidence of head/face and cervical spine injuries in young skiers and snowboarders. Inj Prev 2002;8:324-327.

43 Bally A, Bonjour F: An investigation into ski injuries and equipment in Switzerland: Objectives, means, and observations; in Johnson RJ, Mote CD Jr, Binét MH, (eds): Skiing Trauma and Safety: Seventh International Symposium, ASTM STP 1022. Philadelphia, American Society for Testing and Materials, 1989, pp 51-62.

44 Ekeland A, Holtmoen Å, Lystad H: Skiing injuries in alpine recreational skiers; in Johnson RJ, Mote CD Jr, Binét MH (eds): Skiing Trauma and Safety: Seventh International Symposium, ASTM STP 1022. Philadelphia, American Society for Testing and Materials, 1989, pp $41-50$. 
45 Ekeland A, Holtmoen Å, Lystad H: Alpine skiing injuries in Scandanavian skiers; in Mote CD Jr, Johnson RJ (eds): Skiing Trauma and Safety: Eigth International Symposium, ASTM STP 1104. Philadelphia, American Society for Testing and Materials, 1991, pp 144-151.

46 Greenwald RM, Nesshoever M, Boynton MD: Ski injury epidemiology: A short-term epidemiology study of injuries with skiboards; in Johnson RJ, Zucco P, Shealy JE (eds): Skiing Trauma and Safety, vol 13, ASTM STP 1397. West Conshohocken, PA, American Society for Testing and Materials, 2000, pp 119-126.

47 Hauser W, Asang E, Müller B: Injury risk in alpine skiing; in Johnson RJ, Mote CD Jr, (eds): Skiing Trauma and Skiing Safety: Fifth International Symposium, ASTM STP 860. Philadelphia, American Society for Testing and Materials, 1985, pp 338-348.

48 Kisser R, Goethals B, Wrobel M: Epidemiology for marketing ski safety; in Mote CD Jr, Johnson RJ, Hauser W, Schaff PS (eds): Skiing Trauma and Safety, vol 10, ASTM STP 1266. Philadelphia, American Society for Testing and Materials, 1996, pp 104-115.

49 Lystad H: A one-year study of alpine ski injuries in Hemesdale, Norway; in Johnson RJ, Mote CD Jr (eds): Skiing Trauma and Safety: Fifth International Symposium, ASTM STP 860. Philadelphia, American Society for Testing and Materials, 1985, pp 314-325.

50 Lystad H: A five-year survey of skiing injuries in Hemsdale, Norway; in Johnson RJ, Mote CD Jr, Binét MH (eds): Skiing Trauma and Safety: Seventh International Symposium, ASTM STP 1022. Philadelphia, American Society for Testing and Materials, 1989, pp 32-40.

51 Shealy JE: Overall analysis of NSAA/ASTM data on skiing injuries for 1978 through 1981; in Johnson RJ, Mote CD Jr (eds): Skiing Trauma and Safety: Fifth International Symposium, ASTM STP 860. Philadelphia, American Society for Testing and Materials, 1985, pp 302-313.

52 Shealy J: Snowboard vs. downhill skiing injuries; in Johnson RJ, Mote CD Jr, Zelcer J (eds): Skiing Trauma and Safety: Ninth International Symposium, ASTM STP 1182. Philadelphia, American Society for Testing Materials, 1993, pp 241-254.

53 Shealy JE: Comparison of downhill ski injury patterns - 1978-81 vs. 1988-90; in Johnson RJ, Mote CD Jr, Zelcer J (eds): Skiing Trauma and Safety: Ninth International Symposium, ASTM STP 1182. Philadelphia, American Society for Testing and Materials, 1993, pp 23-32.

54 Boldrino C, Furian G: Risk factors in skiing and snowboarding in Austria; in Johnson RJ (ed): Skiing Trauma and Safety, vol 12, ASTM STP 1345. West Conshohocken, PA, American Society for Testing and Materials, 1999, pp 166-174.

55 Garrick JG, Kurland LT: The epidemiologic significance of unreported ski injuries. J Safety Res 1971;3:182-187.

56 Requa RK, Toney JM, Garrick JG: Parameters of injury reporting in skiing. Med Sci Sports 1977;9:185-190.

57 Shealy J, Geyer L, Hayden R: Epidemiology of ski injuries: Effect of method of skill acquisition and release binding accident rates. Hum Factors 1974;16:459-473.

58 Hagel BE, Goulet C, Platt RW, Pless IB: Injuries among skiers and snowboarders in Quebec. Epidemiology 2004;15:279-286.

59 Ungerholm S, Gierup J, Gustavsson J, Lindsjö U: Skiing safety in children: Adjustment and reliability of the bindings. Int J Sports Med 1984;5:325-329.

60 Oh S, Schmid UD: Head injuries in childhood caused by skiing accidents and optimal prevention. Z Kinderchir 1983;38:66-72.

61 Katagi K: A heady debate. Ski Magazine 2000;October:219-223.

62 Boshra B: Calculating the risks: Helmets aren't the answer to injuries on the slopes, snowboarders say. The Gazette. Montreal, 2001:A3.

63 Shealy JE, Ettlinger CF, Johnson RJ: Rates and modalities of death in the U.S.: Snowboarding and skiing differences-1991/92 through 1998/99; in Johson RJ, Zucco P, Shealy JE (eds): Skiing Trauma and Safety, vol 13, ASTM STP 1397. West Conshohocken, PA, American Society for Testing and Materials, 2000, pp 132-138.

64 Myles S, Mohtadi N, Schnittker J: Injuries to the nervous system and spine in downhill skiing. Can J Surg 1992;35:643-647.

65 Hagel BE, Pless IB, Hanley JA: RE: Upper extremity snowboarding injuries: Ten-year results from the Colorado Snowboard Injury Survey (letter). Am J Sports Med 2001;29:676-677. 
66 Idzikowski JR, Janes PC, Abbott PJ: Upper extremity snowboarding injuries: Ten-year results from the Colorado Snowboard Injury Survey. Am J Sports Med 2000;28:825-832.

67 Machold W, Kwansy O, Eisenhardt P, et al: Reduction of severe wrist injuries in snowboarding by an optimized wrist protection device: A prospective randomized trial. J Trauma 2002;52:517-520.

68 Rønning R, Rønning I, Gerner T, Engebretsen L: The efficacy of wrist protectors in preventing snowboarding injuries. Am J Sports Med 2001;29:581-585.

69 Thompson RS, Rivara FP, Thompson DC: A case-control study of the effectiveness of bicycle safety helmets. N Engl J Med 1989;320:1361-1367.

70 Thompson DC, Rivara FP, Thompson RS: Effectiveness of bicycle safety helmets in preventing head injuries: A case-control study. JAMA 1996;276:1968-1973.

71 Wacholder S, McLaughlin JK, Silverman DT, Mandel JS: Selection of controls in case-control studies. I. Principles. Am J Epidemiol 1992;135:1019-1028.

72 Wacholder S, Silverman DT, McLaughlin JK, Mandel JS: Selection of controls in case-control studies. II. Types of controls. Am J Epidemiol 1992;135:1029-1041.

73 Wacholder S, Silverman DT, McLaughlin JK, Mandel JS: Selection of controls in case-control studies. III. Design Options. Am J Epidemiol 1992;135:1042-1050.

74 Maclure M: The case-crossover design: A method for studying transient effects on the risk of acute events. Am J Epidemiol 1991;133:144-153.

75 Shealy JE, Ettlinger CF, Johnson RJ: What do we know? Things that we ought to know but may have forgotten about ski injury research that relates to binding function, knee and lower leg injuries (abstract). Knee Surg Sports Traumatol Arthrosc 2002;10:389.

76 Laporte J, Bally A, Binet MH: Why have standards for ski binding settings been modified in France (abstract). Knee Surg Sports Traumatol Arthrosc 2002;10:388.

77 Langran M: Injury patterns in skiboarding: A 2-year study in Scotland. Injury 2002;33:563-568.

78 Shealy JE, Ettlinger CF, Johnson RJ: A two-year study of skiboards; in Johnson RJ, Zucco P, Shealy JE (eds): Skiing Trauma and Safety, vol 13, ASTM STP 1397. West Conshohocken, PA, American Society for Testing and Materials, 2000, pp 127-131.

79 Rivara FP, Thompson DC, Thompson RS: Epidemiology of bicycle injuries and risk factors for serious injury. Inj Prev 1997;3:110-114.

80 Schieber RA, Branche-Dorsey CM, Ryan GW, Rutherford GW, Stevens JA, O’Neil J: Risk factors for injuries from in-line skating and the effectiveness of safety gear. N Engl J Med 1996;335: $1630-1635$.

81 Bouter LM, Knipschild PG, Volovics A: Binding function in relation to injury risk in downhill skiing. Am J Sports Med 1989;17:226-233.

Brent Hagel, $\mathrm{PhD}$

Assistant Professor

Alberta Centre for Injury Control and Research

Department of Public Health Sciences, Faculty of Medicine and Dentistry

University of Alberta

4075 RTF, 8308-114 Street, Edmonton, Alta., T6G 2E1 (Canada)

Tel. +1 780492 5099, Fax +1 78049250 99, E-Mail brent.hagel@ualberta.ca 